\title{
WATER SOFTENING AND PURIFICATION BY THE ARCHBUTT-DEELEY PROCESS.
}

\author{
By Mr. LEONARD AROHBUTT, of DeRby, \\ Chemist to the Mideand Rallway.
}

Hard water, so called on account of its soap-destroying property, owes its peculiarities to the presence of compounds of lime and magnesia, chiefly the carbonates and sulphates, but occasionally also the chlorides and nitrates.

Carbonate of Lime, or calcium carbonate, which is the principal constituent of chalk water, owes its presence almost entirely to dissolved carbonic acid. Distilled water, from which every trace of carbonic acid has been expelled by boiling, can hold in solution only about 1.3 grain of carbonate of lime per gallon; but if the water be saturated with earbonic acid it can dissolve as much as 60 to 70 grains, the whole of which, except the above 1.3 grain, is precipitated when the water is boiled and the carbonic acid expelled. All natural water contains carbonic acid, obtained partly from the air and partly from the soil ; and therefore all such water which has been in contact with chalk contains carbonate of lime in solution, and possesses the property of destroying soap and of forming an incrustation in vessels in which it is boiled.

The use of slaked limo, or hydrate of lime, for softening chalk water was first proposed by Thomas Henry, F.R.S., about a eentury ago. Its action depends upon the fact that the lime removes from the water the dissolved carbonic acid, combining with it to form carbonate of lime, which precipitates, and the carbonate of lime previously held in solution by the carbonic acid precipitates also, leaving the clear water soft, except for the very small quantity of carbonate of lime which remains permanently dissolved, and which in natural water usually amounts to about $1 \frac{1}{2}$ to $2 \frac{1}{2}$ grains per gallon. 
The practical success of this process, which depends upon the addition to the water of just the right quantity of lime, is due to the late Dr. Thomas Clark of Aberdeen, who, in his celebrated patent in 1841 , described the method of ascertaining the necessary amount of lime by determining the alkalinity of the water, and also the method of controlling the process on the large scale by the simple and delicate test with nitrate of silver, which indicates, by the brown colour of the precipitated silver oxide, when the slightest excess of lime has been added. This test fails however where, as occasionally happens, the water contains sulphuretted hydrogen. In the same patent, he also described his well-known soap test, by which the hardness of water can be approximately ascertained without analysis; and although the uncertainties of this test when applied to magnesiahard waters have been pointed out by many chemists, it is most useful in testing softened water, being capable of giving good results in the hands of the workman who has charge of the apparatus. Clark's process in its simplest form is perfectly applicable to but few waters, namely to those only of which the hardness is due entirely to chalk. It also requires large and expensive settling tanks to carry it out, unless filters are employed.

Carbonate of Magnesia, though much more soluble in water than carbonate of lime, is usually met with in smaller proportion, seldom ezceeding, according to the author's experience, 5 or 6 grains per gallon. Occasionally he has found 10 or 11 grains, and in one instance, a brackish water from a borehole at Sutton Bridge near Lynn, the exceptional quantity of $28 \cdot 8$ grains per gallon. Carbonate of magnesia can easily be removed from water by treatment with lime; but as it is much more soluble than is usually supposed in water quite free from carbonic acid, merely adding enough lime to remove the carbonic acid will not suffice; it is nocessary to add a sufficient quantity of lime to decompose the carbonate of magnesia, and convert it into hydrate of magnesia which is almost insoluble in water : thus-

$$
\mathrm{Mg} \mathrm{CO}+\mathrm{Ca}(\mathrm{OH})_{2}=\underset{\text { (insoluble precipitate) }}{\mathrm{Mg}(\mathrm{OH})_{2}+\mathrm{Ca} \mathrm{CO}_{3}}
$$


As the traces of dissolved hydrate of magnesia react like lime in the test with nitrate of silver, the yellow or pale brown colour is obtained before sufficient lime has been added to decompose the whole of the carbonate of magnesia; and it is partly on this account that, when such waters are treated by Clark's process, the removal of the carbonate of magnesia is frequently incomplete. There is also another reason. Mragnesia, when set free by lime water, has a tendency to remain in a statc of semi-solution, forming an opalescent liquid which may be kept for sevoral days, and even heated, without the magnesia precipitating; and when an attempt is made to filter water in this condition, the magnesia separates out as a gelatinous precipitate in the pores of the cloth, completely choking them.* On this account, the softening of water containing both carbonate of lime and carbonate of magnesia is frequently limited to the removal of the carbonate of lime; and the carbonate of magnesia is purposely left in the water. It is so at St. Helens, where the Clark process is employed with Atkins filters. Owing to the practical impossibility of filtering out the magnesia, the hardness of the water can be reduced only from 18.5 to 10 or 12 degrees; $\dagger$ but it has been proved by experiment that by doubling the quantity of lime, and precipitating in plain tanks by the special method about to be described, the hardness can be further reduced to 6 degrees, and the extra cost for lime is balanced by the saving in the cost of filter cloths, \&c. [See page 421.]

Sulphate of Lime, or calcium sulphate, which is one of the most objectionable constituents of boiler water on account of the hard crystalline scale it produces, does not owe its solubility to the agency of carbonic acid, but is dissolved by the water itself. It is an exception to the general rule that hot water dissolves more of a substance than cold water. The solubility, it is true, increases from $32^{\circ} \mathrm{F}$. up to about $104^{\circ} \mathrm{F}$; ; but above this temperature it diminishes,

* Archbutt and Deeley; Journal of the Society of Chemical Industry, vol. 10 (1891), page 516 .

$\dagger$ One degree of hardness is caused by one grain of carbonate of lime dissolved in one gallon of water. 
at first slowly, then rapidly, and finally more slowly again, as shown by the following Table 1, and the diagram Fig. 11, Plate 92 :-

TABLE 1.-Solubility of Sulphate of Lime in pure water.

\begin{tabular}{|c|c|c|c|}
\hline Observer. & Temperature. & $\begin{array}{c}\text { Corresponding } \\
\text { Pressure } \\
\text { above atmosphere } \\
\text { per square inch. }\end{array}$ & $\begin{array}{c}\text { Sulphate of Lime } \\
\text { (anhydrous) } \\
\text { dissolved by } \\
\text { I gallon of pure water. }\end{array}$ \\
\hline Marignac ${ }^{3}$ & $\begin{array}{c}\text { Fahr. }^{\circ} \\
32 \\
68 \\
104 \\
140 \\
176 \\
212\end{array}$ & $\begin{array}{l}\text { Lbs. } \\
= \\
= \\
\overline{0} \\
\overline{0.0}\end{array}$ & $\begin{array}{c}\text { Grains. } \\
133 \cdot 0 \\
144 \cdot 2 \\
149 \cdot 8 \\
145 \cdot 6 \\
136 \cdot 5 \\
121 \cdot 8\end{array}$ \\
\hline $\begin{array}{l}\text { Tilden and } \\
\text { Shenstone }{ }^{2}\end{array}$ & $\begin{array}{l}284 \\
324 \cdot 5 \\
356 \cdot 5 \\
473\end{array}$ & $\begin{array}{r}37 \cdot 8 \\
80 \cdot 8 \\
132 \cdot 0 \\
513 \cdot 5\end{array}$ & $\begin{array}{l}54 \cdot 6 \\
39 \cdot 2 \\
18 \cdot 9 \\
12 \cdot 6\end{array}$ \\
\hline
\end{tabular}

1 Annales de Chimie et de Physique (5), I, page 274.

2 Philosophical Transactions, part I, 1884.

It is commonly stated, apparently on the authority of Sullivan,* that sulphate of lime is quite insoluble in water at a temperature of $302^{\circ} \mathrm{F}$., equivalent to a boiler pressure of 55 lbs. per square inch; but Tilden and Shenstone's experiments in Table 1 show that even at $473^{\circ} \mathrm{F}$, a temperature far beyond the range of any ordinary steam boiler, pure water can retain in solution $12 \cdot 6$ grains of sulphate of lime per gallon. The solubility of sulphate of lime in natural water is influenced by the presence of other substances with which it is associated. Thus it is increased by the presence of common salt; but the amount dissolved by the salt water diminishes as the temperature is raised. At $437^{\circ} \mathrm{F}$. however, a solution containing 21 parts of common salt to 100 of water can still retain in solution $0 \cdot 178$ part of sulphate of lime, or $124 \cdot 6$ grains per gallon. $\dagger$ In

* British Association Reports, 1859, page 292.

$\dagger$ 'Tilden and Shenstone, Proceedings of the Royal Society, vol. 38 (1885), pages 331-336. 
saturated brine, Lewes states that sulphate of lime is insoluble. Sulphate of soda is said to increase the solubility of sulphate of lime. Chloride of calcium, on the other hand, diminishes it, but does not reduce it to nil until the proportion of 50 of calcium chloride to 100 of water is reached. Chloride of magnesium increases the solubility at the ordinary temperature, but at higher temperatures appears to behave similarly to calcium chloride.

This point has been dwelt upon, because there is a certain class of apparatus, sold for preventing scale in steam boilers, which depends for its usefulness upon the supposition that the carbonate and sulphate of lime are rendered insoluble by the mere heating of the feed water; but so far as the sulphate is concerned, Tilden's experiments prove that such apparatus cannot be efficient, especially that kind in which the feed water is passed into the boiler through a tube in the steam space, where the water occupies only a few minutes in its passage through the tube. In Tilden's experiments the heating was continued for $4 \frac{1}{2}$ to 5 hours. What happens in a steam boiler, working at say $140 \mathrm{lbs}$. pressure, is probably as follows:-the water, containing say 5 to 10 grains of sulphate of lime per gallon, besides carbonate, first loses its carbonic acid and deposits the carbonate of lime, partly as mud and partly as: scale; the water then concentrates by evaporation, until the sulphate of lime reaches the saturation point; and then the sulphate of lime gradually crystallizes out, mainly upon the plates, cementing the carbonate of lime into a hard scale, so long as the evaporation continues. To suppose that by merely heating the water under pressure, without concentration, the sulphate of lime is entirely thrown down, is contrary to the results of Tilden's experiments; and it is doubtful whether even the carbonate of lime is more than partially precipitated under these conditions, unless the water is actually boiled sufficiently to expel the carbonic acid.

As the solubility of sulphate of lime in water does not depend upon the presence of carbonic acid, this salt is not precipitated when the carbonic acid is removed by the lime treatment. Before sulphate of lime can be removed, it must be decomposed, which can 
be done by adding sodium carbonate, when the following reaction occurs :-

$$
\mathrm{Ca} \mathrm{SO}_{4}+\mathrm{Na}_{2} \mathrm{CO}_{3}=\mathrm{Ca} \mathrm{CO} \mathrm{CO}_{3}+\mathrm{Na}_{2} \mathrm{SO}_{4}
$$

that is, the sulphate of lime is decomposed, carbonate of lime is precipitated, and sulphate of soda remains in solution. The water is softened, because the sulphate of soda does not decompose soap; and being an easily soluble salt, it does not form scale in steam boilers. But in this case there is not a diminution but a slight increase in the total solids, 136 parts of sulphate of lime being replaced by 142 parts of sulphate of soda.

Temporary versus Permanent Hardness. - In the removal by the lime process of the so-called "temporary hardness," that is, the hardness due to the carbonates of lime and magnesia, these compounds are rendered insoluble and precipitated without anything being introduced in their place; the total solids of the water are therefore diminished exactly to the same extent that the hardness is reduced. But in removing the "permanent hardness," that is, the hardness due to the sulphates and other compounds of lime and magnesia, these compounds are not precipitated unchanged, but are replaced by other salts of a less objectionable and more soluble character, and the dissolved solids are slightly increased. Such softened water therefore should not, any more than unsoftened water, be allowed to concentrate indefinitely in stean boilers, but should be regularly blown off and replaced by fresh water from time to time; or the boilers should be completely emptied at regular intervals of not too long duration. If this be done, no trouble will be experienced; but if the water be allowed to concentrate too far, priming may occur, and even scale may be formed. It would seem incredible that such neglect should be possible; but Paul * gives two analyses of actual scale produced by neglect of blowing off or washing out, one containing 68 per cent. of common salt, taken from the boiler of a Thames tug, and the other containing 77 per cent. of common salt, 12 per cent. of sulphate of soda, and 3.6 per cent. of

* See Civil and Mechanical Engineers, 1891. 
carbonate of soda, taken from a land boiler in Berkshire; of this latter scale 95 per cent. dissolved at once on immersion in cold water. These incrustations were not produced by softened water, but by natural water highly charged with sodium salts. The tendency to prime is most marked in the cuse of locomotive boilers, and is not unfrequently aggravated by the pernicious and dangerous practice of putting oil into the boilers; but there seems no doubt that a moderate concentration of the sodium salts, more especially sodium sulphate, will sometimes cause it. Where there is no objection on other grounds, such boilers may with advantage be fitted with seum cocks, by which the surface water can be blown off down to a safe level whenever required.

Chloride and Nitrate of Calcium, sometimes met with in hard water, are very soluble salts, which do not enter into the composition of boiler incrustation; but they destroy soap. They are decomposed by sodium carbonate, similarly to calcium sulphate; the calcium is precipitated as carbonate, and sodium chloride and nitrate remain in solution.

Sulphate, Chloride, and Nitrate of Magnesium are also easily soluble salts, which are not constituents of ordinary boiler incrustation. Sulphate of magnesia may nevertheless prove a highly objectionable substance, if allowed to concentrate in the boiler. A soft carbonate of lime incrustation, when boiled with a solution of sulphate of magnesia, is gradually transformed into sulphate of lime and hasic carbonate of magnesia, which latter, if the temperature be high enough, changes into hydrate of magnesia, and the two together then form a hard scale like porcelain, thus :-

$$
\mathrm{Ca} \mathrm{CO}_{3}+\mathrm{Mg} \mathrm{SO} \mathrm{H}_{4}+\mathrm{H}_{2} \mathrm{O}=\underbrace{\mathrm{Ca} \mathrm{SO}_{4}+\mathrm{Mg}(\mathrm{OH})_{2}}_{\text {hard scale }}+\mathrm{CO}_{2}
$$

Chloride and nitrate of magnesium are objectionable, owing to their corrosive character. All these salts decompose soap, forming a greasy scum on the water. The hardness caused by either of the above compounds of magnesium can be removed by adding to 
the water caustic soda, or, what comes to the same thing and is cheaper, lime and carbonate of soda in proper proportions, by which these magnesium compounds are decomposed and the magnesin is precipitated as hydrate. When caustic soda is used, the reaction is :-

$$
\mathrm{Mg} \mathrm{SO}+2 \mathrm{Na} \mathrm{OH}=\mathrm{Mg}(\mathrm{OH})_{2}+\mathrm{Na}_{2} \mathrm{SO}_{4} ;
$$

and when lime and carbonate of soda are used :-

$\mathrm{Mg} \mathrm{SO} \mathrm{Sa}_{4}+\mathrm{Na}_{2} \mathrm{CO}_{3}+\mathrm{Ca}(\mathrm{OH})_{2}=\mathrm{Mg}(\mathrm{OH})_{2}+\mathrm{Ca} \mathrm{CO}_{3}+\mathrm{Na}_{2} \mathrm{SO}_{4}$. Thus, all hard water can be softened by means of either lime alone or lime and sodium carbonate, in proportions which depend upon the character of the water to be treated; but a water may be so hard as to be unsuitable for softening, owing to the cost of the chemicals required and to the excessive proportion of soluble salts remaining in the softened water.

Carbonating Softened Water.-Hard water is, as a rule, an extremely dilute solution of the substances which it is wished to remove from it; and the changes which occur when it is chomically softened require time for their completion. These changes are both more rapid and more complete if the hard water and re-agents are heated together, than if they are mixed when cold; and water which has been softened when cold is liable to deposit a furthor small quantity of precipitate on heating. Attention was called to this fact at Derby several years ago, during the experimental softening of water for use in some of the stationary boilers in the locomotive works.* When the softening process had been in operation for several months, and the improved condition of the boilers was such that the President was considering the desirability of extending the process to the whole of the boilers, a difficulty of a peculiar kind presented itself. It was found that the softened water which formed no scale in the boilers had quite the opposite effect in the injectors, feed pipes, and clack boxes. The valves began to give trouble by sticking, and an examination proved that the whole interior of the feed apparatus was coated with a soft deposit, which was gradually

* Journal of the Society of Chemical Industry, vol. 10 (1891), page 515. 
choking everything. Some of the deposit removed from the interior of one of the copper pipes gave the following results on analysis:-

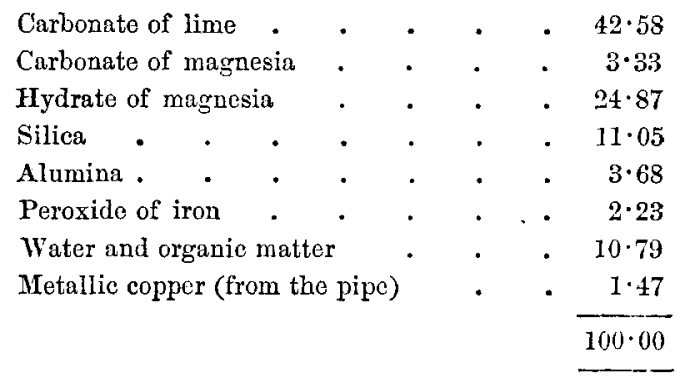

The large amount of magnesia in this deposit, and the fact that carbonate of lime and hydrate of magnesia occur in it in proportions which are chemically equivalent, whilst in the water itself the ratio of magnesia to lime was much less, afforded a clue which was followed up by heating some of the clear softened water in a glass flask to about $200^{\circ} \mathrm{F}$. Nothing appeared to separate at first; but on shaking the water round in the flask an exceedingly thin film peeled off the surface of the glass, and broke up into fragments which floated about in the water. These fragments were found to consist of carbonate of lime and magnesia. The cause of the deposit was now apparent. The chemical reaction between the lime and the carbonate of magnesia-

$$
\mathrm{Mg} \mathrm{CO}+\mathrm{Ca}(\mathrm{OH})_{2}=\mathrm{Irg}(\mathrm{OH})_{2}+\mathrm{CaCO}_{3}
$$

which was not quite complete in the cold, completed itself when the water became raised in temperature in the hot pipes, and a slight further precipitation took place. The four boilers using softened water at that time were all supplied by means of one exhaust injector, and through this injector and the feed pipes about 20,000 gallons of water passed in 24 hours. Assuming that each gallon of water deposittd one-third of a grain of solid matter, the total amount of deposit formed in one day would amount to nearly one pound. If thrown down in the boilers, 
this would have amounted to nothing more serious than a little harmless mud; but by its precipitation in the feed pipes the narrow passages were gradually choked up. The experiment was subsequently made of passing a little carbonic acid into some of the clear softened water before heating, and this was found entirely to prevent further precipitation at $200^{\circ} \mathrm{F}$. The remedy therefore lay in carbonating the softened water; and eventually a coke stove was set up, and the gases from it were led into the softened water in sufficient proportion to convert all the carbonates into bicarbonates, which is easily ascertained by means of phenol-phthalein solution. Since then no further trouble has been experienced.

It may here be pointed out that passing carbonic acid into the clear softened water cannot possibly harden it, though some appear to think it can. It is true that for softening hard water lime is added in order to remove the carbonic acid; but this is only in order that the dissolved carbonate of lime, which is held in solution by the carbonic acid, may precipitate; after removal of the carbonate of lime, as much carbonic acid as desired may be put back into the water without hardening it. Every natural soft water contains carbonic acid, and so long as it does not come into contact with calcareous strata it remains soft. Carbonating the softened water is in fact an advantage, not only when the water is required for feeding boilers, but for some other purposes, such as wool-washing and tanning, because all traces of free caustic alkali and carbonate of soda remaining in the softened water, which would be detrimental, are converted into bicarbonates. By this process softened water is made more palatable for drinking, and the tendency to form a deposit in town mains is lessened, if not entirely obviated.

Softening Apparatus.-The mechanical operations involved in the softening and purification of hard water include the preparation of the re-agent, the mixing of it with the hard water, the separation of the precipitate, and the subsequent bicarbonating of the softened water. The apparatus and process employed must be of the simplest possible character compatible with efficiency, and should be applicable to the removal of both temporary and permanent hardness, whether due to 
lime or to magnesia salts. Nothing could be simpler than the original Clark process of precipitation in plain tanks; but the slow settling of the precipitate necessitated either large and costly tanks or the use of filters; and filtration, besides complicating the process, has been found to be troublesome and expensive when the water contains magnesia, and practically unworkable if any attempt be made to remove the magnesia. In the process about to be described plain tanks are used and filters are dispensed with; for by a special method of manipulation it has been found possible to increase the rate of subsidence of the precipitate to such an extent that about onesixth of the tank area required in Clark's process is usually sufficient. This effect is produced mainly by the simple expedient of stirring up, every time a tankful of water is softened, some of the precipitate which has settled from previous operations. This precipitate by lying at the bottom of the tank becomes aggregated into coarse flakes, which, when stirred up and allowed to settle again, carry down the fine particles of fresh precipitate so rapidly that in from half an hour to an hour the water clears itself to such an extent that the suspended matter remaining, even at a depth of 6 feet from the surface, does not exceed about 1 grain per gallon. This very small quantity may for many purposes be neglected; and when perfectly clear water is required the subsequent carbonating re-dissolves it, hardening the water it is true to the extent of one degree or less, according to the amount in suspension, but not sufficiently to be of material importance.

In Plates 87 to 89 is shown the general arrangement of apparatus suitable for treating on this principle from 5,000 to 10,000 gallons of water per hour. The two exactly similar softening tanks TT, preferably $10 \frac{1}{2}$ feet deep, are intended to be used alternately, one being - filled with water which is being softened and clarified, whilst a supply of purified water is being drawn off from the other. For 4,000 gallons per hour, or less, one softening tank is sufficient, with a storage tank; for more than 12,000 gallons per hour three tanks are desirable; and for 35,000 gallons and upwards, four tanks. The working capacity of each softening tank is three-fourths of its depth, about $2 \frac{1}{2}$ feet of water and mud being allowed to remain when the water is 
drawn off, while a margin of 6 inches at the top is left in filling, which is done by means of the supply pipe I. The quantity of water to be treated being thus exactly known, the proper quantities of quicklime and anhydrous carbonate of soda (58 per cent. alkali) are weighed out. The lime is first slaked in hot water in one of the small re-agent tanks RR, Figs. 8 to 10 , Plates 90 and 91, which is filled with water, either from a tap connected with the softenedwater main, or direct from the softening tank by means of the tee and pipe between the three-way tap $A$ and blower B, Figs. 4, 8, and 9 , by turning on steam to the blower, throttling the passage through the three-way tap to the two vertical downward pipes $G$ and $K$, and opening the tap D, Fig. 10, the tap $E$ and the air tap being closed; water is then lifted into the tank through the rose $J$ and suction pipe $S$, Fig. 4, Plate 89 . The water is boiled by a perforated steam coil C, Figs. 9 and 10. After the lime has been completely slaked, the alkali is added, and the liquid is boiled for a few minutes and stirred until the alkali is dissolved. The re-agent thus prepared is injected into the hard water in the softening tank through the upper row $U$ of horizontal perforated pipes, Fig. 4, in the following manner:- the tap $D$ and the air tap being closed, steam at not less than $45 \mathrm{lbs}$. (preferably $90 \mathrm{lbs}$.) pressure is admitted to the blower B, Fig. 9, and the three-way tap $A$ is turned so that a current of water is established from the softening tank, through the rose $J$, Fig. 4, the suction pipe S, Figs. 4 and 9, and the three-way tap, down the vertical pipe $G$, and back into the tank through the perforations on the upper side of the upper row $U$ of horizontal pipes. Into this current of water the re-agent solution is slowly admitted by opening the tap E, Figs. 9 and 10, and is diffused throughout the volume of hard water in the softening tank. The operation, including the rinsing of the re-agent tank, is generally allowed to occupy ten minutes. The suction pipe in the re-agent tank extends below the perforated false bottom F, Fig. 9, which prevents any pieces of stone \&c. in the lime from getting into the pipe. The tap $\mathrm{E}$ having been shut off, the air-tap over the blower $\mathrm{B}$ opened, and the three-way tap A reversed, air is forced down the pipe K, Fig. 4, and through the perforations in the under side of 
the lower row $L$ of pipes, into the mud at the bottom of the tank, stirring up a portion of the mud and diffusing it through the water. After the blower has been in operation for a few minutes-usually ten, but varying with different waters - the steam is shut off, and in about an hour or less the water will be ready to be drawn off.

The operations of carbonating and drawing off are effected simultaneously by means of the floating discharge-pipe P, Figs. 3, 4,6 , and 7 , the body of which is of brazed copper, rectangular in section, having bafles (Fig. 6) at intervals along the bottom; these cause the water to flow down in a cascade and to splash up into the gases, which are injected from the coke stove into the cast-iron head of the pipe through the gas-pipe $\mathrm{N}$. The water and surplus gas escape together at the lower end through a ball valve, the carbonated water falling into the cistern (Figs. 2, 3, and 4) from which it is drawn for use, and the gas escaping into the air. The coke stove, Fig. 5, Plate 89, contains in the upper part a supply of coke, which, by falling through the cone, maintains a fire of constant thickness, about 8 inches in depth over the fire-bars. The top of the chimney, Fig. 4 , is closed by a butterfly valve, below which the gas is drawn off through a branch for carbonating. In order to ensure a constant and ample supply of gas, a small blower is fixed in the branch pipe. When the ball valve closes and water ceases to flow down the discharge pipe $P$, the gas accumulating in the head of the pipe forces the water below the sill M, Fig. 6, and escapes through the pipe $O$ without disturbing the water in the tank. When the ball valve opens again, the floating pipe $P$ first empties itself of water, and the gas then escapes through the ball valve, relieving the pressure, and allowing water again to pass over the sill $\mathrm{M}$ and down the pipe $\mathrm{P}$ with the gas, so long as the valve remains open.

The precipitate is prevented from unduly accumulating in the tanks by its partial removal at regular intervals; this is effected in various ways to suit difforent eireumstances. From the nature of the precipitate, and the fact that it is not allowed to consolidate, it is easily dealt with. In a small apparatus a mud pipe leading to a drain is provided near one corner of the tank; and by lifting a plug daily, and using the blower to stir the mud, a sufficient 
quantity can be run off. In a larger apparatus it is swept out into a pipe or trough, which conveys it into shallow draining pits, whence it can be carted away; or, it is raised from the tank or trough by a steam lifter, and discharged direct into a cart or wagon lined with waste furnace-ashes, through which the excess of water soon drains, leaving the nearly dry mud and ashes ready for tipping.

General Remark8. - The softening of water is an exact process, and in order to obtain satisfactory results proper attention must be given to it. Rough and ready methods may succeed in a few instances, but they will not answer in the long run for general adoption. Automatic machines for softening water, which are said to require attention only once or twice a day, and which run continuously, are not to be recommended. In the comparatively rare cases where lime alone is required, and the hard water is practically invariable in character, the continuous method of mixing the hard water with lime water in properly proportioned streams may give good results, provided the machine for preparing the lime water is thoroughly efficient and properly attended to. Lime water is a saturated re-agent; it can be prepared of nearly constant strength by causing water to flow continuously through a mass of it kept in agitation, and the solution, being very dilute, does not need extremely fine measurement. But when the same plan is adopted with a solution of caustic soda of much greater strength, finer measurement is necessary; and, unless it be carefully looked after, a deficiency or an excess of re-agent in the softened water may easily occur. Another objection to the continuous-flow system of softening is that, unless frequent tests are made, a large quantity of improperly treated water may pass from the apparatus. Therefore it is preferable to soften a known volume of water with a known weight of chemicals, and to test each tankful; the excess or deficiency of re-agent can then never be serious, even with a variable water. With the tanks fitted as above described, the manipulation of 20,000 or 30,000 gallons of water is as easy as that of one gallon; the appliance for mixing is effective and easily kept in order; every tankful of water may be treated with whatever weight and kind of chemicals are desired, and every drop of water 
gets its proper proportion. The labour is light. No expensive buildings are required ; all that are necessary are a storehouse for lime and coke, and a covered working stage over the tanks; and the apparatus generally is almost indestructible, necessary repairs being limited to keeping the valves in order, occasionally cleaning out the holes in the perforated pipes, and painting the tanks outside; experience shows that they do not rust inside.

River Derwent Water,-This process has been in operation since January 1892 in the Midland Railway Works at Derby, clarifying and softening the sewage-polluted water of the River Derwent; reducing the hardness from about 15 degrees to $4 \frac{1}{2}$ or 5 degrees, and effecting considerable organic purification, at an inclusive cost for chemicals, labour, and interest on outlay, of about one penny per thousand gallons. A photograph of the apparatus is shown in Plate 86. The tank on the left hand is being drawn from, that in the middle is blowing, and that on the right hand is filling. The water is of variable character. The following analyses recently made show the composition of the water before and after softening, and are plotted in the diagram, Fig. 12, Plate 92 :-

Unsoftened Water. Softened Water.

Grains per Gallon.

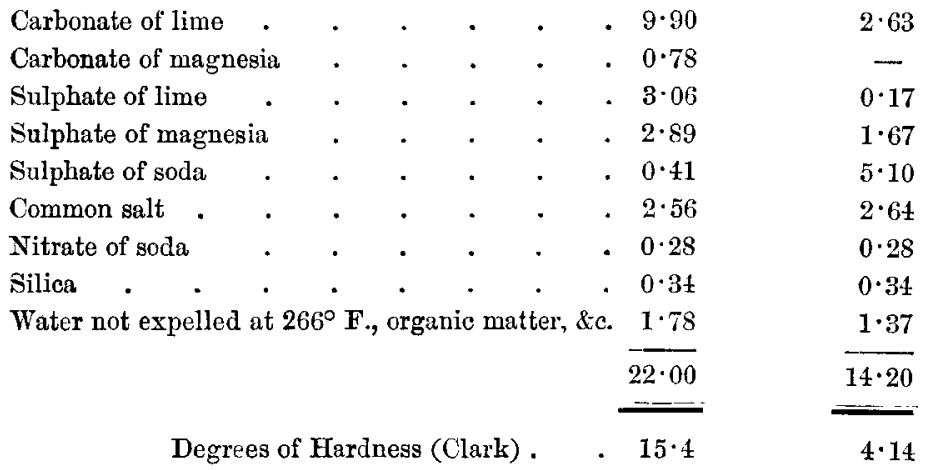

By using more lime and alkali, the hardness can be reduced to 3 degrees, and the sulphates of lime and magnesia wholly removed; 
but as the softened water is used in locomotives, it is found desirable not to reduce it so low.

The organic purification effected is shown by the following figures :-

\begin{tabular}{|lr|c|c}
\hline & $\begin{array}{c}\text { Water } \\
\text { from pump main } \\
\text { as delivered } \\
\text { into tanks. }\end{array}$ & $\begin{array}{c}\text { Same Water } \\
\text { after treatment } \\
\text { and 30 minutes' } \\
\text { subsidence. }\end{array}$ \\
\hline Free ammonia. & Parts per million & 1.15 & 1.08 \\
Albuminoid ammonia. & Parts per million \\
$\begin{array}{c}\text { Oxygen absorbed } \\
\left.\text { in 4 hours at } 80^{\circ} \mathrm{F} .\right\}\end{array}$ & Grains per gallon & 0.42 & 0.28 \\
\hline
\end{tabular}

Bacterial Purification.-Of greater importance from a sanitary point of view is the remarkable bacterial purification effected by this process, which the polluted character of the unpurified River Derwent water brings into special prominence. Before treatment the water swarms with bacteria capable of growing on a gelatine plate; after treatment, few are left in the water. This is illustrated by the two photographs, Fig. 17, Plate 94. Dr. Percy Frankland. showed, several years ago, that the precipitate of carbonate of lime produced in Clark's process carries down about 98 per cent. of the organisms contained in the water; the author's own experiments show that the repeated stirring up of the old precipitate does not impair the efficiency of the purification in this respect, even when the mud is swarming with bacteria, as that in the tanks at Derby must be.

The author and Mr. Deeley are greatly indebted to the President for kind help in many ways, and especially for having, by the erection of the Derby plant, enabled the capabilities of their process to be demonstrated.

Other Applications.--During the last five years this process has been adopted for softening water at upwards of fifty works at 
home and abrcad, including water works, dye and bleach works, woollen and worsted mills, paper mills, laundries, \&c., where the quantities of water treated by it range from 500 to 45,000 gallons per hour. It has been found to be applicable to all kinds of hard water, and gives the best results when magnesia is present, the hydrate of magnesia forming a coarser precipitate which settles more rapidly than pure carbonate of lime. The following is an example of a very hard well-water, strongly impregnated with magnesia, which is successfully softened at Nottingham:-

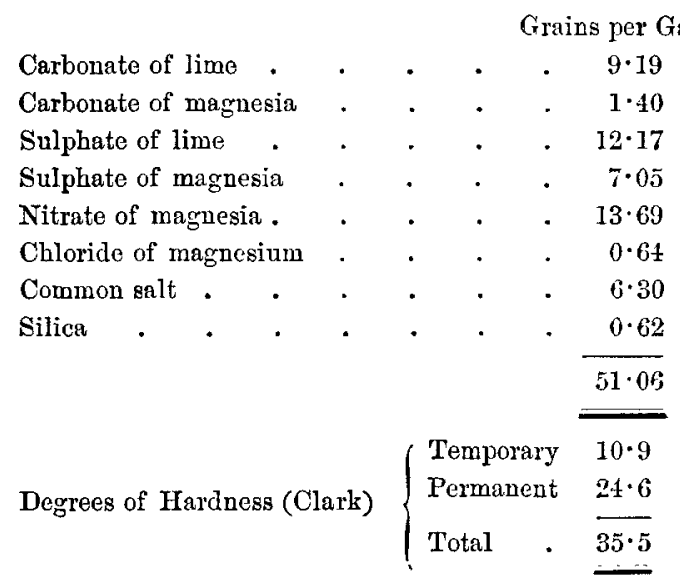

This water, after softening, at a cost for chemicals of about $2 \frac{1}{2} d$. per thousand gallons, has an average soap hardness of $3 \cdot 2$ degrees, all the permanent hardness is removed, and the temporary hardness is reduced to 3.2 degrees. The softened water is used for wool washing and steam raising; it forms no scale in the boilers, and the economiser tubes are kept free from incrustation.

St. Helens.-The advantage of this process when applied to magnesia-hard water has recently received a practical demonstration at St. Helens. The following information is from notes kindly supplied by Mr. Lackland, the water engineer :-

"The water supply to St. Helens is at present obtained from four pumping stations on the new red sandstone. That from two of 
the stations is treated by the Clark process, being softened by the addition of milk of lime in a continuous operation; after passing through a subsiding tank of 130,000 gallons, and then through eloth filters, it flows into a service reservoir. The quantity of water thus softened varies from $1 \frac{1}{2}$ to $2 \frac{1}{2}$ million gallons per day of twenty-four hours. The hardness before treatment is 18.5 degrees, and after treatment from 10 to 12 degrees; and the quantity of lime used is about 20 ounces per thousand gallons.

"The difficulty in applying the Clark process to the St. Helens water has been considerable, in consequence of the presence of magnesia as well as carbonate of lime, the effect being that the reaction in the softening process is not fully completed until after the water has passed the filters; and although the water is good in appearance on leaving the filters, yet a white deposit is subsequently found in the reservoir, probably due in most part to the delay in the reaction with the magnesia salts, but also in part to a certain amount of carbonate of lime and small particles which the cloth filters allow to pass at intervals, after being cleansed by sprays of water. This sediment flnds its way into the mains, and occasionally appears at the taps in the houses, giving rise to much complaint from time to time. In order to remedy this defect, and also to aroid the waste of water which takes place from the frequent flushing of the mains, it was decided in 1897 to try the Archbutt-Deeley process. For this purpose, an experimental apparatus was supplied by Messrs. Mather and Platt, and trials were made in December, January, and February last. The result of this experiment on the large scale was to show that by the addition of 40 ounces of lime per thousand gallons the water could be reduced to 6 degrees of hardness, as against an average of 12 degrees by the Clark process, and that the occurrence of a white sediment in the reservoir could be entirely avoided. There is also the advantage that filters are not required." With the Clark process it is not practicable to use more than 20 ounces of lime per thousand gallons for the reason explained in page 406, that the magnesia thereby precipitated chokes the filters.

Mr. Lackland estimates that the extra cost of lime by the Archbutt-Deeley process will be balanced by the saving in the cost 
of filter cloths and other expenses incurred by the Clark process at present in use; and of course there will be the additional advantage that the hardness of the water will be reduced to 6 degrees, instead of to 10 or 12 degrees as at present.

The following is an analysis of the St. Helens water from the Knowsley and Kirkby pumping stations, recently made in the author's laboratory by Mr. T. H. Adams :-

\section{Grains per Gallon.}

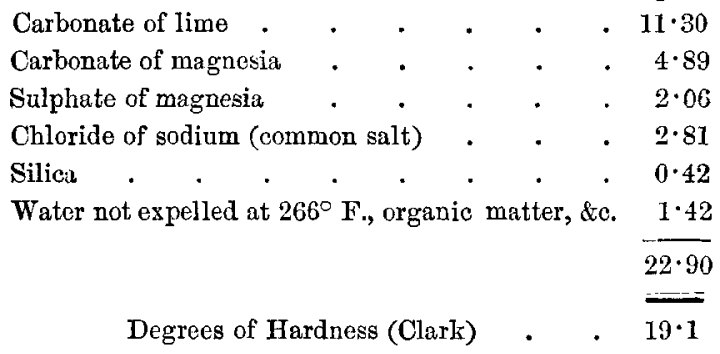

From this analysis it may be seen that by removing 9 grains of carbonate of lime and no magnesia, as in Clark's process, the hardness would be reduced to $10 \cdot 1$ degrees; by removing also the carbonate of magnesia, a further reduction of 5.8 degrees of hardness is possible, the 4.89 grains of carbonate of magnesia being equivalent to $5 \cdot 8$ degrees of hardness.

Swadlincote and Ashby. - An interesting example of the application of this process to a public water supply is afforded at the new waterworks designed by Messrs. George and F. W. Hodson for the Joint Water Committee of the Swadlincote and Ashby Urban District Councils. The water, which is pumped from a well and boreholes in the Trent gravel at Milton, near Repton, besides being very hard, contains in solution a considerable amount of iron, which precipitates on exposure of the water to light and air. This iron is successfully and completely removed, the hardness of the water is reduced from 22 or 23 degrees to an average of $8 \frac{1}{2}$ degrees, and the softened water is bicarbonated, at a total inclusive cost-for chemicals, labour, steam for the blower, coke 
for carbonating, and interest at 6 per cent. on capital outlay-of 0.8 penny per thousand gallons, according to figures kindly furnished by Messrs. Hodson. Here 2 per cent. is allowed for depreciation and 1 per cent. for repairs, which is considered ample for such a plant. Lime only is used in softening this water. The presence of the iron, instead of being a trouble, is an advantage in the purifying process, as it assists the precipitation, which is remarkably rapid. The tanks are $10 \frac{1}{2}$ feet deep; and forty minutes after shutting off steam from the blower the water is clear, almost to the bottom of the tank, and ready to be drawn off. The guaranteed output of the plant is 45,000 gallons per hour, or 540,000 gallons per day of twelve hours; this quantity of water is easily softened and purified in four tanks, each having a working capacity of 27,000 gallons. Messrs. Hodson state that the purified water gives complete satisfaction to the whole of the consumers, and is being largely laid on to works of various manufacturers in the district. Fig. 14, Plate 93, is a general view of the works. On the left hand is the pumping house and the engineer's residence, on the right are the softening tanks with the chemical treating house above, and in the foregound is the well and reserve tank for hard water. Fig. 16, Plate 94, shows the interior of the treating house; and Fig. 15, Plate 93, is a view of the softening tanks as seen from above. For these photographs the author is indebted to Mr. Deeley.

Cost of Softening.-In the discussion upon Mr. Tebbutt's recent paper on steam laundry machinery (Proceedings 1898, page 297), Mr. George H. Hughes stated that the cost of softening water by Dr. Clark's process amounted to probably about one penny per thousand gallons, including three farthings for labour, maintenance of plant and tanks, and interest on capital, and one farthing for lime or other chemicals. Information as to the cost of softening water at several places has also been given by Mr. W. R. Bird,* who obtained his information from the engineers of the various works. He states that the total cost of the Clark process at Canterbury, at the East Surrey

* Junior Engineering Society of Swindon in November 1895. 
Water Works, and at the South Hants Water Works, is about one penny per thousand gallons, interest being probably reckoned at 5 per cent., though this is not mentioned. The same process with Atkins filters costs at Saffron Walden $2 \cdot 12$ pence, at Wellingborough $2 \cdot 07$ pence, at Henley $1 \cdot 35$ pence, and at Southampton 0.43 penny. The low cost at Southampton is partly accounted for by the large volume of water softened, namely $2 \frac{1}{4}$ million gallons per day, which considerably reduces the cost per thousand gallons for interest and labour. Interest is charged at 5 per cent., which allows only 2 per cent. for depreciation and repairs; but as the most valuable part of the plant consists of filtering machinery, 5 per cent. for depreciation and repairs would be a fairer charge, making 8 per cent. altogether; if this were allowed, it would increase the cost at Southampton to 0.54 penny per thousand gallons. At St. Helens, where from $1 \frac{1}{2}$ to $2 \frac{1}{2}$ million gallons are at present softened per day by the same process as at Southampton, Mr. Lackland gives the total cost as 0.67 penny per thousand gallons; $£ 310$ per annum, or one-sixth of the whole cost, is for renewal of filter cloths. Messrs. Hodson state that the Porter-Clark process, which they carried out in Suffolk for a small supply of 50,000 gallons per day, where a chalk water was reduced in hardness from 28 to 10 degrees, was found to cost $2 \cdot 27$ pence per thousand gallons for lime, labour, steam, renewals of filter cloths, and 5 per cent. interest on outlay.

General statements as to the cost of softening water by any particular process must be misleading, because so much depends upon the quantity as well as the character of the water treated. A water of which the hardness is entirely "temporary," that is, due to carbonate of lime and carbonate of magnesia, can be softened with lime alone, which costs, per ton, say $£ 1$ or less ; but "permanent" hardness, due to sulphate of lime, can be removed only by using alkali, costing at present prices nearly $£ 5$ per ton. Less than one pound of $\operatorname{lime}$ per thousand gallons of water will remove 10 degrees of temporary hardness; but 1.6 pound of alkali is required for the removal of 10 degrees of permanent hardness due to sulphate of lime, while sulphate of magnesia is still more expensive to remove. Taking quicklime at $£ 1$ per ton, and alkali at $£ 5$ per ton, the cost 
of the chemicals required for softening water is about as follows per thousand gallons :-

For every 10 degrees of temporary hardness . . . 0.11 penny.

" " " " permanent,$\quad . .0 .95 "$

Thus permanent hardness is approximately nine times as expensive to remove as temporary hardness. These figures for the cost of chemicals are quite independent of the particular mechanical process employed: except that caustic soda, which is used in some water softeners, increases the cost. Clark's process is never used for any other purpose than the removal of temporary hardness, and this is why the cost of softening by that process is low. Assuming the cost of labour, interest on outlay, and other incidental expenses, to amount to 0.5 penny per thousand gallons, the cost of softening water of 20 degrees hardness would vary as follows, according to the nature of the hardness, as shown in the diagram Fig. 13, Plate 92 :-

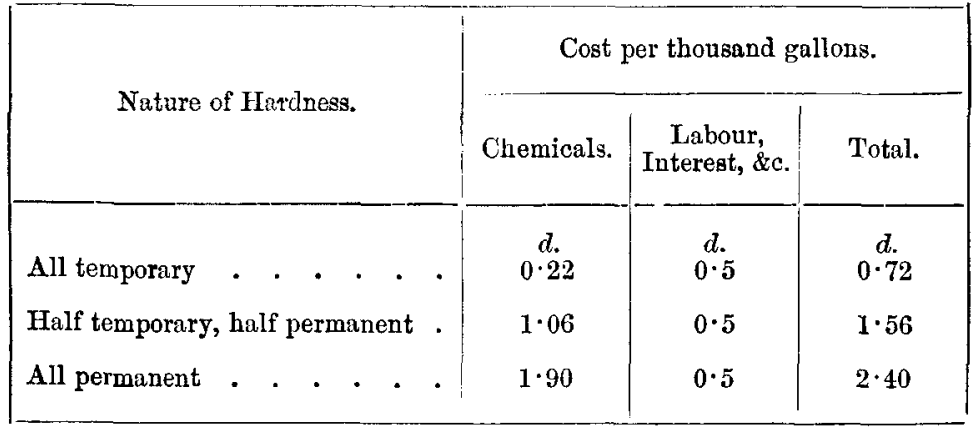

Advantages of Softening.-The incrustation deposited upon the tubes and other heating surfaces of steam boilers using hard water is generally believed to lead to considerable waste of fuel, owing to its badly conducting property; but authorities are not agreed as to the amount of waste that may thus be caused, which must in any case depend upon the kind of boiler and upon the nature as well as the thickness of the incrustation. It has been stated by one observer* that 1-16th inch thickness of incrustation on the tubes of a multitubular

* Quoted in page 165 of "A Treatise on Steam Boilers" by Robert Wilson, 1879. 
boiler is equivalent to a loss of 20 per cent. of fuel, and that the loss increases with the thickness of the incrustation in a rapid ratio. Professor Lewes * gives the latest estimates as showing that 1-6th inch of scale necessitates the use of 16 per cent. more fuel, 1-4th inch 50 per cent., and half an inch 150 per cent. additional coal. Another writer $\dagger$ thinks that the loss of fuel has been greatly exaggerated; and states, as an illustration, that the boiler of a steamtug, the tubes of which when taken out were found to be partly cemented into a solid mass by a stone-like incrustation, was proved to have consumed but little more coal in the last six months than in the first six months during a period of three years; it is added however that the engineer in charge of this boiler was careful to keep the flues free from soot and ashes. But waste of fuel is not the only evil produced by incrustation. In a perfectly clean boiler, the temperature of the plates over the hottest fire is not much above that of the water in contact with them; but the incrustation formed by hard water allows the plates to become overheated, with the result that a more rapid wasting of the metal takes place, and there is a danger of collapse if the scale is allowed to become too thick. Grease or greasy incrustation opposes a much greater obstacle to the transmission of heat than clean scale does; and, as is well known, hundreds of cases of collapse of flues, and even more serious accidents, have been caused by overheating due to grease or greasy deposits in boilers. Such greasy deposits are frequently met with when the feed-water, containing carbonate of lime, is heated by the exhaust steam from the engine cylinders, especially when the lubricant contains animal or vegetable oil. This is not the place to discuss the cause of the formation of such deposits; but it is desirable to point out that, by softening such water, not only is the carbonate of lime removed, but the traces of grease in the water are carried down with the precipitate.

The chief advantages of softening hard water for boilers, apart from the saving of fuel, are therefore-increased safety of working,

\footnotetext{
* "Service Chemistry" 1889.

† "Treatise on Steam-Boiler Incrustation." Davis.
} 
longer life of the boilers, and a great saving in the cost of cleaning and repairs. It has even been found that in a range of boilers the cost of an extra boiler may be saved, owing to the smaller amount of repairs and the saving of time required for cleaning. There is no doubt that, to avoid incurring the cost of a softening apparatus, much more money is frequently spent in "boiler compositions" than would pay for properly softening the water. Many of these nostrums are useless, and some dangerous, whilst the best are only a partial remedy for the evils complained of.

Pitting and corrosion of boilers are not likely to be caused by properly softened water, unless it be allowed to concentrate unduly; neither can the use of such water of itself canse leakage. Corrosion of brass cocks and gauge fittings most likely arises from the use of alkali in excess, which is simply due to neglect. Pitting of boilers, even where apparently caused by softened water, may really be due to the uncovering of old "pits" by the removal of scale, which always occurs when softened water is first used in a dirty boiler. Pitting when once started is likely to continue, owing to galvanic action between the metal and the crust of oxide of iron contained in the cavity. By thoroughly scraping the pits so as to remove every trace of this oxide, and by then painting the dry metal surface with a thin coating of mineral lubricating oil, Mr. Deeley has found pitting to cease in many instances when the water was kept slightly alkaline. Leakage of the boiler plates sometimes occurs soon after commencing to use softened water in an old boiler, and is sometimes wrongly attributed to the chemicals used in softening the water; it is more likely to be due to the loosening of the old scale, which had covered up defective places.

The softening of water is a necessity in all cases where soap has to be used, as in the washing, milling, and scouring of textile fabrics. For such work a great saving may be effected by a properly constructed softening apparatus, without which the softening must be expensively done with soap or soda. The advantage may be judged from the fact that 1,000 gallons of water of only 10 degrees hardness will destroy $12 \mathrm{lbs}$. of the best hard soap, costing say. $2 s . ;$ the same quantity of water can be softened 
by $1 \mathrm{lb}$. of lime costing about one-tenth of a penny, or by $1 \cdot 6 \mathrm{lb}$. of alkali, costing rather less than one penny, and the soap is saved. One firm state that they save 40 per cent. of soap and 25 per cent. of alkali by using their own well-water softened from 12 to 3 degrees, instead of using town water of 7 degrees hardness. Several firms testify to the saving of soap in wool washing, and to the improved results obtained by the use of softened water for dyeing, especially where the dyes are applied in neutral or slightly alkaline baths. The material is less liable to fleck, the formation of objectionable lime lakes with the alizarine dyes is aroided, and the colours obtained are more brilliant than when hard water is used. It should not be forgotten that, in any laundry where hard water is used, all the water must be softened in the wash-tub before a lather can be obtained; and this is done at the cost of soap and soda wastefully used, and with all the objectionable lime and magnesia soap soum left in the water. By adopting an efficient water-softener, not only is there a great saving in soap and soda, but less rubbing of the clothes is required, and hence less fraying of collars, \&c. ; also, when the water is properly softened, the cages of the washing machines are kept free from incrustation.

Clarification of Waste Water.-This process is not limited to the softening of hard water, but has proved very effectual in the clarification of manufacturers' waste water. During the last three or four years apparatus has been supplied for this purpose to about twenty-five works of various kinds, including bleach and dye works, calico-printing works, paper mills, cloth mills, \&c., and gives great satisfaction. No novelty of chemical treatment is adopted, but it is found that the thorough method of mixing leads to a great economy of chemicals; and owing to the rapidity of precipitation there is also considerable economy in the amount of tank capacity required. Lime and alumino-ferric are the chemicals chiefly used. The clarification of the water is perfect, and when desired the alkalinity of the effluent is neutralised by carbonating. The water is also decolourised. Plate 95 is from a photograph of apparatus at the Standish Bleach and Dye Works, Wigan, where 75,000 gallons of 
waste water are treated per hour in four brick tanks. For this photograph, and for the tracings from which Plates 87 to 91 have been prepared, the author is indebted to Messrs. Mather and Platt, Salford Iron Works, Manchester, who are the makers of the apparatus.

\section{Discussion.}

Mr. John I. Thonnycroft, Member of Council, said the paper dealt so completely with the chemical and mechanical operations, and gave so clear an insight into what took place in the softening of water, that he thought it ought to prove of great service to engineers. The author was right in saying that there was great waste from not properly softening water; and he had shown one way in which this waste could be remedied. There was one point on which he must confess he was himself somewhat in the dark, namely in regard to the plan of carbonating the water after it had been softened (page 413), and thereby re-dissolving the lime and carbonate of magnesia which might be remaining in the water in such a state that they were liable to form a deposit. Although that plan surmounted one difficulty, it seemed to him that perhaps it might entail the risk of raising another, owing to the action of carbonic acid in parting with its oxygen to the iron. It appeared to him possible that this action might cause an increase of corrosion in boilers; and probably the author had had experience in the matter, and would be able to dispel the doubts he had in his mind. Having himself been concerned with boilers in which the thickness of iron was so slight that he could not afford to lose any metal if it could be helped, he might be specially sensitive on this point; and therefore he should like to know whether there was any trouble in connection with the carbonic acid which was purposely introduced into the water. Experiments had been made by Mr. Weir, in which he appeared to show that the real trouble of corrosion was due to carbnnic acid; and ho therefore considered it necessary to boil the 
(Mir. John I. Thornycroft.)

water and so remove the carbonic acid from it before putting it into the boiler, because he had found it was a dangerous thing to have carbonic acid in the boiler. The details of the apparatus which had been described by the author were most interesting, and seemed to him to be complete.

Mr. J. F. L. Crosland considered that water-softening apparatus was a most important adjunct to the working of steam boilers in many places. As regarded the estimate given in page 426 as to the amount of loss of fuel caused by the thickness of the incrustation in boilers-namely 16 per cent. for 1-6th inch, 50 per cent. for 1-4th, and 150 per cent. for half an inch-his own experience went to show that these figures were greatly exaggerated. Scale only 1-16th inch thick, quoted from another observer as equivalent to a loss of 20 per cent. of fuel, he thought made scarcely any appreciable difference in the consumption of fuel. Having tested a steam boiler when it had been quite clean, and again a few weeks afterwards when the incrustation had become a little thicker than an egg-shell, he had found the difference in coal consumption was scarcely a measurable quantity. In one instance he remembered boilers being put in during the Christmas week, and they were afterwards examined in February, when there was found to be 3 inches thickness of deposit over the whole bottom; yet scarcely any difference had been noticed in the fuel, not enough to cause any special comment. It was therefore clear that incrustation half an inch thick would not increase the quantity of coal used to the extent of 150 per cent., or there would have been something said about it at those works. It would be highly desirable to make some experiments on this matter; but meanwhile he thought half an inch thickness of hard scale would not increase the cost of coal even so much as the 16 per cent. which was ascribed in the paper to only 1-6th inch thickness. Hard scale in itself did not seem to prevent the transmission of heat in anything like the ratio that a soft scale would, such as a deposit purely of carbonate of lime in the form of a flour. A floury deposit of 1-16th inch thickness was much more injurious than half an inch of hard scale of flinty character. It was where he had been troubled 
with a light floury deposit that ho had found the water-softening apparatus most useful. In 1864 he remembered meeting with some boilers at Scarborough, in which it seemed impossible to keep the furnaces in repair. They had been repaired in all kinds of ways : hoops had been put round them, they had been hung up by bolts at the sides, and everything possible bad been done to strengthen them. It could not be discovered at the time why they were constantly collapsing. Finally inspectors were employed to watch them day and night, and they were never left for a moment; and the furnace crowns could be seen coming down even when there were 6 or 8 or 10 inches of water above them. At last it was suggested that there must be something peculiar about the character of the water. It was extremely good water, being the drinking water of Scarborough; but it contained carbonate of lime, which deposited on the plates in a floury state; and the only remedy then known consisted in blowing off at the surface, which removed the trouble. That difficulty which existed in a great many places in the country could be almost entirely got rid of by the particular water-softening apparatus now described, and also by some others. Wherever the peculiar floury deposit was found, it was essential for the good working of the boilers that some apparatus of this kind should be used. There was no kind of composition, or any other means of dealing with the water, that would prove equally effectual : constant blowing off involved great waste of fuel. In page 426 it was pointed out that "grease or greasy incrustation opposes a much greater obstacle to the transmission of heat than clean scale does;" and "such greasy deposits are frequently met with when the feed-water, containing carbonate of lime, is heated by the exhaust steam ;" and "by softening such water, not only is the carbonate of lime removed, but the traces of grease in the water are carried down with the precipitate." It was not usual however to treat water after it had been heated by exhaust steam; and amongst ${ }^{7}$ a large number of boilers for which the feed-water was so heated he did not know of any one instance where the water was softened after it had been heated by exhaust steam. Such a procedure would result in cooling the water again. Where the grease was mostly troublesome was just where 
(Mr. J. F. L. CrosIand.)

softening apparatus had hitherto been least likely to be used, namely where the feed-water was obtained from a surface condenser, and where the make-up water containing carbonate of lime caused overheating of the plates. The difficulty arising from grease being carried into the feed-water by the exhaust steam could easily be obviated by diverting the steam through tubular heaters. There was no doubt that water softening ought to be much more adopted than it was. Boiler compositions, as properly stated in page 427, were many of them useless, and some dangerous; they contained grease or oil or fatty matter, and other objectionable things, and sometimes matter which produced corrosion. Those that were of any service were mostly composed of soda; but as a rule they were of little use indeed. If boiler users were troubled with anything more than say 5 or 6 grains of carbonate of lime per gallon, a water-softening apparatus should certainly be adopted. With regard to corrosion (page 427), a water-softening apparatus would not have to be used, he imagined, for simply corrosive water, but only for water which also contained a large quantity of solid deposit dissolved in it. Where the latter occurred, and where there was also corrosive action in the water, owing perhaps to the presence of salt and other impurities, the very process of water-softening by the introduction of lime and soda had also the same effect of preventing the corrosive action of the water. Any serious injury to the brass fittings of boilers he agreed in thinking need not be anticipated from the use of softened water. If too much soda was introduced, the fittings undoubtedly would suffer, as rightly pointed out; but that would be due either to neglect or to ignorance. The softening apparatus was extremely valuable; and in view of the greatly increasing pressures that were used in such boilers as had been referred to by Mr. Thornycroft (page 429), it was absolutely essential that almost pure water should be used. To have water laden with a deposit of from 20 up to even 120 grains per gallon, as was frequently the case, would be absolutely fatal to the use of a complex boiler of the tubulous kind. Wherever tubulous boilers were used at high pressures, and where such deposits occurred, it was absolutely essential that there should be a good water-softening apparatus. 
Mr. Edwand B. Eifington, Member of Council, considered the process described in the paper was most valuable, and the paper itself would be of great service to many members of the Institution; its authors were to be congratulated upon the excellent results they had evidently obtained. Apart from the supplementary introduction of carbonic acid to complete the chemical efficiency of the apparatus, the important mechanical result attained was that the settling process had now been accomplished in a much smaller tank area than hitherto; it was the large tank area previously required which had constituted the difficulty in a great many instances in using the Clark process. His own experience in the matter had been rather in the clarification of dirty water than in the softening process itself. In one of the pumping stations, situated at Millbank in London, the water for the hydraulic power supply was pumped up from a well which went down to the gravel bed overlying the London clay. All that water was impregnated with iron in exactly the same way as that pumped from the Trent gravel at Milton (page 422), where the author's process was in use; and it was necessary to adopt some chemical means of getting rid of the iron it contained, which was gradually precipitated on exposure to the light and air. The area was limited, and it was necessary to provide a large amount of storage for the clarified water, in order to be prepared for contingencies. After careful consideration and investigation of the various plans, he had adopted the Porter-Clark process, and had now had it at work about ten years. The lime was used not primarily for the purpose of softening the water, but for getting rid of the iron and providing means for filtering it out by the filter presses. The water was mixed with a saturated solution of lime, which was pumped at a regular speed into a softening tank having a capacity of 15,000 gallons; the total eapacity of the apparatus was 30,000 gallons per hour. The great cost of the process was in connection with the filter presses; the cloths became so rapidly destroyed that about one-third of the total cost of the process was for cloths alone. The quantity treated per week was about two million gallons. The total cost for labour, cleaning the cloths, working the filter presses, filter eloths, power, and all other charges enumerated in page 424 , 
(Mr. Edward B. Ellington.)

amounted to about $1 \frac{1}{1}$ penny per thousand gallons; this was in contrast with the cost of $2 \cdot 27$ pence mentioned in page 424 for the same process at a place in Suffolk, where however the quantity filtered was so much smaller. The working in London had been perfectly successful. Apart from the renewal of the filter cloths, the repairs had been practically nil; and the apparatus worked day and night, and was really automatic in its action. When the filtered-water tanks were full, the apparatus was stopped; and that was all the attendant had to do at night. The reaction evidently was not always completed in the softening vessel; and in case the apparatus was out of order, and therefore necessarily out of use, in one of the tanks a bed of charcoal was prepared, which could be used as a filter. The whole of tho water, after passing through the filter presses, was passed through this filter, and a certain amount of lime deposit was invariably found in it. This charcoal filter had to be cleaned out once a fortnight, in order to get rid of the lime; while it was being cleaned out a fresh bed of charcoal in another of the tanks was doing the final filtering. If it were not for these charcoal filters some of the lime would get into the hydraulic mains; as a matter of fact no lime had ever been found in the water after it had passed the filtering tanks. Nearly equally good results in clarifying the water had been obtained without any lime at all. At the first pumping station erected, where about three million gallons a week could be treated, sponge filters were used. The water was simply strained through sponge; and there were certain mechanical means of cleaning the sponge periodically. That plan worked well so long as the apparatus was in order; but it frequently got out of order, and was costly to repair. Under those conditions the effuent was not of a sufficiently satisfactory character. "Torrent" charcoal filters had now been added, in which the charcoal was cleaned by blowing in air with the cleansing water, and so disturbing the charcoal while the washing was going on. There was now therefore a double process of filtration, once through the sponge and then once through the charcoal; and the clarified effuent-which was water taken from the Thames at Blackfriars, and was in a filthy condition when pumped up-was as bright and clean as water treated by lime. In an 
extension which was now in progress at the Millbank station, filter presses had been abandoned, and "Torrent" filters were going to be depended on entirely for getting a clear effluent after treatment with lime. From experiments that had been made for some timo with a small charcoal filter, he believed this plan would prove perfectly successful.

With reference to the use of alumino-ferric for the clarification of water (page 428), he had used this chemical for a good many years for helping clarification, not at the station where the Porter-Clark process was used, but at the first station where no lime was used. After the alumino-ferric had been in use for some time, complaints were received of corrosion of wrought-iron pipes on the consumers' premises. This had not occurred previous to the use of the aluminoferric. A great deal of trouble and care were taken to ascertain the cause if possible; but no satisfactory conclusion could be arrived at, except that the corrosion itself was undoubtedly due to the presence of oxygen in the water, and that if the oxygen were eliminated no corrosion could take place. But his suspicion was aroused with regard to the action of the alumino-ferric, and after some time its use was abandoned; and since then, so far as he knew, the corrosive action which had been complained of had ceased. He should therefore like to know from the author whether any such result would be likely to follow from the use of alumino-ferric; and whether, if it was used, it was necessary to take some further steps for neutralising its subsequent action in the clarified water.

Mr. Arthur J. Henschmann referred to Berenger and Stingl's plan of water purification, which had been in use since 1878 in Austria, where the question? of water-softening was of great interest to mill-owners and boiler-users, because there boiler companies had taken more steps to ensure the proper working of boilers than probably in many other countries. In agricultural districts an endeavour had been made to prevent the incrustation of boilers by the introduction of potatoes, the object being to form a gelatinous enclosure round any contaminations in the boiler water, and prevent them from becoming, deposited as scale in the boiler. Another 
(Mr. Arthur J. Herschmanu.)

method was to paint boilers internally with a tarry or oil paint. Tho use of hydrate of lime, as mentioned in page 404, had been known in this country about a century ago, much before the Clark process was adopted. In Germany, amongst many processes in use for removing temporary hardness, those of Bohlig, De Hüen, and Schulze worked on similar lines to one another. The Berenger and Stingl apparatus was the first to accomplish that object chemically and more thoroughly by means of caustic soda and hydrate of lime. Caustic soda transformed the bi-carbonates into simple carbonates, which became precipitated, the caustic soda itself becoming transformed into carbonate of soda. It could not long remain carbonate of soda, because hydrate of lime was in the solution; and it again became transformed into caustic soda, precipitating carbonate of lime. These mutual reactions continued to take place so long as any hydrate of lime was left. After the latter was all used up, the remaining carbonate of soda precipitated the gypsum or sulphate of lime in the water. It was attributed to the co-existence of the hydrate of lime and caustic soda that an efficient purification of water was efficted.

Professor Annold Lupton asked how, when the feed-water had been heated by the exhaust steam from the engine cylinders (page 426), the softening process could be subsequently carried out without cooling. It occurred to him that the cooling might take away a great part of the heat put into the water by the exhaust steam.

Mr. John Perrs had had many years' practical experience in the softening of water for steam boilers by means of the Howatson process, from which good results had been obtaincd. The water to be treated contained as much as 65 grains of hardening ingredients per gallon, chiefly sulphate of lime and sulphate of magnesia. Although good results had been obtained, serious difficulties had at first been experienced in the feed pipes. After the water had left the softener and had settled in the tank from which the injector or the steam pump drew, the pipes leading to the injector or pump got choked up in two or three months, not with a soft mud, but with a hard 
scale. They had to be taken down, and sometimes they were cleaned, and at other times they had to bo replaced by now pipes. He had tried injecting fuel gas into the water, but with bad results inside the boiler; for corrosion set up to a remarkable extent, and he was obliged to cease using it. After the feed-water had left the injector, that is, between the injector and the boiler, the pipes were perfectly free. Consequently he had turned his attention to heating the feedwater, instead of injecting fuel gas into it. Commencing with heating the water up to only $100^{\circ} \mathrm{Fahr}$., he had met with some success, but not complete; and had gradually increased the heating up to $180^{\circ}$, when the result was that the feed-pipes were perfectly clear, and no further trouble at all was experienced. [Sce page 452.]

Mr. Droit thalpin noticed that in Table 1 (page 407), showing the permanent hardness as represented by the solubility of sulphate of lime in pure water at different temperatures, one of the observers gave one set of figures and the others a different set; whilst immediately afterwards an authority was quoted for the statement that the whole of the permanent hardness, that is the whole of the sulphate of lime, was got rid of at $302^{\circ} \mathrm{Fah}$. From his own experience he was more inclined to believe in the latter statement. In a translation (published in the Transactions of the Institution of Civil Engineers of Ireland, 1861, vol. 6, pages 268 and 318) of a paper by M. Cousté (Annales des Mines, 1854, vol. 5, page 69), the temperature at which the whole of the sulphate of lime was precipitated was given as $302^{\circ} \mathrm{Fahr}$. This certainly was more in accord with his own experience, because in heating water without any chemicals at all, simply for the purpose of thermal storage, and using water having originally $18 \frac{1}{2}$ degrees of hardness, the water after having been heated to about $350^{\circ} \mathrm{F}$. had been uniformly found to have only 5 or $5 \frac{1}{2}$ or 6 degrees of hardness. In page 408 it was pointed out that apparatus for preventing scale in boilers by heating the feed-water could not be efficient where the feed-water was merely heated by passing it into the boiler through a tube in the steam space, and where consequently the water occupied only a few minutes in its passage through the tube. This he was quite prepared to believe, and the difficulty he 
(Mr. Druitt Halpin.)

thought could be got over by allowing a reasonable time for the precipitate to settle. If at least three hours were given for depositing. as was now being done by himself on a large scale, the whole of the precipitated sulphate and carbonate of lime would be got out of the water. The first object was to get the hardening ingredients precipitated by the high temperature; and the second was to let the precipitate settle, down by giving it a sufficient amount of time to do so.

As to incrustation causing a loss of fuel going up to 150 per cent. for balf an inch thickness (page 426), with smaller losses for smaller thicknesses, he could not possibly bolieve that incrustation could have such a badjeffect; but he was not prepared to say that it did anything but harm, as far as heat transmission was concerned. The greater the rate of heati transmission, the more deleterious became the incrustation. In the paper announced for reading upon the results of recent practical experience with express locomotive engines on thel North "Eastern Railway, it would be noticed that the locomotive boilers approximated to those of torpedo-boats, inasmuch as they were evaporating at an average rate of about 13 lbs. of water per hour per square foot of heating surface so high a rate of heat transmission was nearly three times that occurring in mill boilers. Locomotive boilers therefore would naturally be those in which the incrustation would have the greatest effect, and where any means of watcr softening would be of the greatest benefit. Although it was so great a necessity, it was difficult to soften water for locomotives by the usual chemical methods, except at the places where the water was put into the tenders from tanks; but if the softening, instead of being done in that way, was done merely by heating, without any use of chemicals, it could be done effectively. At present such an arrangement was at work on twelve lines of railway, on which careful tests had been made under the most severe climatic conditions, generally at or a little below freezing temperature; and on those twelve lines the result of the experiments showed that the minimum saving realised in coal was 16 per cent., while the maximum was 42 per cent. 
Mr. Edwand G. HurLer considered that the essential feature of the apparatus described in the paper, which distinguished it from others for the same object, lay in the blowing arrangement for disturbing the precipitate at the bottom of the tanks, and shaking it up in the water, and so bringing down the new precipitates with it. In connection with that arrangement he should be glad to know more about its effect in regard to greasy water. It seemed to be implied by a previous speaker (page 435) that in Austria more attention was being given to these matters than in England. Whilst he was not prepared to admit that commercial boilers in other parts of the world received better attention than in this country, it was possible that more erudite experiments had been made. In this country the boiler insurance companies had for many years past steadily set their faces against heating the feed-water by blowing the exhaust steam into it, because the steam would carry grease into the feedwater, and the grease would afterwards get into the boiler and lead to overheating of a bad kind. In the softening tanks it was pointed out in page 426 that the traces of grease in the water were carried down with the precipitate; and in this particular he should like to have more information with reference to the precise action of the precipitate. A most interesting principle had here been adopted in the tanks, and it seemed similar to that of the flocculent precipitate utilised for clarifying sewage, and in other similar processes. If the flocculent precipitate carried down with it the grease contained in the water, it not only afforded a testimony to the efficacy of the apparatus in that particular direction, but it also bore upon other apparatus which was being used at the present time, which hitherto he had regarded with some scepticism. In the Boby-Chevalet feedwater heater, for instance, it was claimed that the precipitation of the carbonate of lime by the direct use of exhaust steam was accompanied by the removal of the grease, and also allowed of feeding the boiler with water at boiling point. In that heater the feed-water along with the exhaust steam passed down over a number of trays; and it was supposed that the grease was absorbed by the carbonate of lime which was precipitated by the water being heated in that 
(Mr. Edward G. Hiller.)

manner. Any more definite information which the author could give upon this point he was sure would be most useful, because there were others who like himself were in doubt as to how far that cleansing action actually took place, and to what extent the precipitate acted as a filter on the grease which was in the water. From the description given of the softening apparatus, he imagined that it had not yet brought the users of only one or two boilers any nearer to the goal of having their feed-water purified outside the boiler at an economical rate; it might possibly be applicable to large ranges of steam boilers with advantage. Even 5 per cent. he thought was too little to allow for depreciation (page 424); for he had never seen any of the purifying tanks which had been used for so long as fifteen or twenty years; and he should expect, if proper provision were to be made for depreciation, that ten years' working would probably be nearer the average for the softening tanks and machinery.

Mr. George D. Hughes wished he could be wholly relieved from the suspicion that the pitting and corrosion of boilers arose in some way from the carbonic acid generated by this process. From his own experience of using water containing a large amount of carbonate of lime he believed it was injurious to boilers; and he was sure it was still more so to the human frame: both alike became silted up by water highly charged with carbonate of lime and earthy matter. In consequence of this, for the last ten years he had used distilled water for domestic purposes. The vessels however which contained the distilled water he had found became corroded, as though by an acid; distilled water kept in tin vessels corroded them through in a few weoks. He had therefore had to use vessels coated inside with silica; even with this coating put in, it was found that the distilled water had some effect in dissolving it. Any information the author could give as to what was the cause of distilled water having the effect of corroding a metallie vessel would be welcome; and perhaps those who had some experience in the use of surface condensors could say whether any such corrosive action took place in boilers when using distilled water in sea-going steamers. 
Mr. E. C. Stromerer, referring to the plan of heating the feedwater after it had passed through the clarifying process, but without injecting carbonic acid into it (page 437), enquired how the water was heated, and what was the effect upon the heating surface of the heater, if any. No doubt the scale would be got rid of in the feedpipes, but it would still be present somewhere. Or if the operation consisted simply of blowing steam into the water, there would be a precipitate which would also give trouble somewhere. With regard to the loss arising from the heating surface of the boiler being coated with scale, he quite agreed with Mr. Crosland (page 430) that the efficiency of the boiler was but slightly reduced by scale. The scale would certainly have a great effect, if the hot gases or flames were of one and the same temperature over all the extent of the heating surface. The statements quoted in page 426 were presumably the results of experiments made with small kettles placed over laboratory fires or smiths' furnaces, where the temperature of the flame would be practically uniform. Under such conditions he could understand that, the thicker the scale, the less water would be evaporated, and the figures given in the paper might be correct. But in a steam boiler, where the hot gases travelled over many hundred square feet of heating surface, the circumstances were different. If, as was usual, the heating surface was coated with scale, especially over the furnace crown, it was certain that the furnace end of the boiler would not be so efficient as it would otherwise be. But then the gases would not be so much cooled down at this part as they would otherwise be; and when they reached the next portion of the heating surface, they would be able, being hotter, to transmit more heat than if they had been well cooled by clean and efficient furnace-plates; and proceeding step by step to the end of the heating surface, the final result would be found to be that, although the distribution of evaporation in a clcan and in a scaly boiler would be different, yet the total evaporation would be about the same in both. This he thought would be largely the explanation of the difference between the statements quoted in the paper and the practical experience of engineers in charge of boilers; but it did not get rid of the serious objection to allowing scale to accumulate in a 
(Mr. E. C. Stromeyer.)

boiler. Such an accumulation caused ovcrheating of the plates, and excessive wear and tear at the seams and flanges; and really efficient water-purifiers were therefore deserving of every encouragement.

Mr. James Atrinson thought that, in connection with the effect of boiler scale, it was important to bear in mind that many of the experiments on this point bad been made upon boilers containing flue tubes, through ! the inside of which the hot gases went, while the water was outside. Scale on the outside of such tubes increased the area of their heating surface. But modern boilers were now frequently water-tube boilers, and scale on the inside of these tubes diminished the area of their heating surface. Supposing a 2-inch flue-tube had half an inch of scale put all round it outside, 50 per cent. more heating surface would be obtained. But if a 2-inch water-tube had half an inch of scale all round it inside, the heating surface would be diminished by 50 per cent. This he thought was a highly important consideration, and one that ought always to be kept in view in the transmission of heat through scale. As far as his own experience went, a little hard scale did not much diminish the transmission, nothing like the 150 per cent. mentioned in page 426 ; but with a soft scale there was no doubt a much greater loss than with hard scale.

Mr. William Ingham (Manchester) drew attention to overheating of boiler plates which took place where no deposit was formed either of a hard or of a floury kind, and where also there was no appearance of grease when the boiler was emptied. No doubt the floury deposit referred to by Mr. Crosland (page 430) had been found far more deleterious, or far more likely to cause overheating, than a hard scale. Overheating however took place also simply by a thickening of the water, owing to the quantity of solid matter held in suspension, without the formation of any actual incrustation upon the heating surface. In many instances which he had known, the admission of grease and the floury deposit of carbonate of lime and especially of magnesia had caused such a thickening of the water itself that the transmission of heat to it had been seriously 
retarded, to such an extent indeed that the plates had been gradually overheated and bulged, while no trace of incrustation could be discovered when the boiler was emptied; the deposit had simply gone away with the water. The anticipation entertained by Mr. Thornycroft (page 429), that corrosion might be caused by the presence of carbonic acid in the water, was shared by himself; for he had found that much of the deposit which was taken out of pittings was composed of an oxide of iron resulting from the carbonate. No doubt galvanic action took place when pitting was once started (page 427), in consequence of the oxide of iron, which was obtained from the pittings, acting as an electro-negative element to the iron upon which it rested. A piece of carbon, or a minute speck of other substance which was electro-negative to the iron, wouid cause the electro-positive iron to oxidise round it; and small holes or pits were thus produced. It seemed likely therefore that, if by the carbonating process any excess of carbonic acid were put in, it would prove highly injurious to the boiler. At any rate the pittings and corrosion in a boiler might certainly be aggravated thereby.

Mr. Wirliam Sisson supported the somewhat unpopular opinion promulgated by Mr. Atkinson (page 442), that there was a considerable difference between the effect resulting from the deposition of the scale on the outside of a flue-tube with which the water was in contact, and that resulting from deposition on the inside of a water-tube. It seemed to him that the explanation of the fact, of which there could be no doubt, that a considerable thickness of hard seale did not affect seriously the evaporative power of a boiler, was simply that the resistance to the transmission of the heat from the fire to the water was largely a question of surface resistance, and that a tube otherwise clean, but having a little rust on its surface, was almost as bad for transmission of heat as a tube with one-sixteenth of an inch of scale on it. If there was a hard deposit of scale in close contact with the outside of a flue-iube, the transmission of heat through the joint thickness of the iron or steel and the scale was not much inferior to the transmission through the 
(Mr: William Sisson.)

iron or steel itself. The two bounding surfaces, namely the inside surface of the iron and the outside surface of the scale in the one case, or the two surfaces of the iron itself in the other, were those which presented the greatest resistance to the transmission of heat. Moreover the smoothness of a clean surface was less favourable to heat transmission than the slight roughness of a coating of scale.

Professor Robert H. Smith agreed with $\mathrm{Mr}$. Sisson that a large proportion, perhaps the greater part, of the resistance to the passage of heat from the hot gases to the water was surface resistance, that is, resistance at the surface between the gases and the iron or steel plate, and again at the other surface between the plate and the water; and the latter resistance, between the surface of the plate and the water, was not much affected by the fact of there being a coating of scale or not. With regard to the great difference that had been mentioned between the effect of soft sludge and of hard scale, it seemed to him that it was not really any difference at all in respect of the conduction of heat. It was a difference much more largely due he thought to preventing the generated steam from getting away freely. When there was soft sludge, the water went into and through it, and the steam was generated at the bottom or innermost surface of the sludge, and there was greater resistance to its getting away through the sludge. The efficiency of the steam surface of a boiler, as was well known by all who either constructed or used boilers, depended much more upon the generated steam getting away freely than upon anything else: far more than upon the conductivity of the boiler plates. Where there was a hard scale, the steam was still generated at the bounding surface of what was yet pure water, or comparatively pure water; and if the heating surfaces were properly arranged there was comparatively little resistance to its liberation. The difference of soft sludge from hard scale in its effect upon the transmission of heat was thus more in convective than in conductive effect; that is, the sludge hindered the flow of steam away from the steam-generating surface and the flow of water towards it. 
Mr. Alfred Saxon believed it was recognised in locomotive practice that if the tubes were not cleaned inside they would probably suffer more from dust inside them than they would from the scale outside. In locomotives therefore a practice was made of cleaning the tubes out periodically; and accordingly in stationary steam boilers he submitted that greater inefficiency would probably arise from the neglect of the flues than from the deposit of scale inside the boiler shell. The use of some such softening process as that described in the paper he quite agreed was necessary, especially with hard water; but it seemed to him that the cleaning out of the flues and tubes contributed quite as much to the efficiency of a steam boiler.

Mr. Wrlliam H. Maw, Vice-President, considered the desirability or undesirability of using a water-softening apparatus in connection with boilers was purely a question of cost. Much of the value of the present paper arose from the fact that it gave such complete information as to the cost of the process here advocated. Its value would be yet further enhanced if the author would add particulars of the number of gallons per square foot which could be evaporated by boilers using the softened water before cleaning became necessary. With London water he found that boilers could not be worked advantageously to evaporate more than 250 to 350 gallons of water per square foot of surface between two successive cleanings; and if they were worked within this limit the cost of cleaning was from $1 d$. to $2 d$. per thousand gallons evaporated, being proportionately less in large than in small boilers. According to these figures it appeared that, if the water-softening process was absolutely perfect, and cleaning could be entirely done away with by using it, the saving in the cost of cleaning the boilers would quite pay for the softening, without taking into account any of the other advantages gained by using softened water. London waterwas much like the town waters found elsewhere throughout the country generally; it was a fair average water, and he thought the average cost in other towns was not far different from the London 
(Mr. William H. Maw,)

cost. With regard to the effect of incrustation in diminishing the evaporative efficiency of boilers, he entirely agreed with what had been said by Mr. Crosland (page 430). In boilers working with London water he was quite sure that, if they were not worked longer than about a thousand hours between successive cleanings, the difference in efficiency between a clean boiler and one that was just going to be cleaned was not measurable by the ordinary means available in factories.

Mr. A. Tannett WalkeR, Member of Council, had recently visited a large steelworks in Germany where 10,000 tons of steel wero made per week. In showing him somo new mills and blast furnaces, and various apparatus and improvements that had been carried out, one of the owners of the works had told him there was no improvement that had been carried out there in the last few years which had rendered such grand service as the purifying and softening of the water used throughout the whole of the works: there was now no Sunday work of cleaning, nor any unusual cleaning of the locomotive boilers; and the money that had been saved was almost incredible. This had made so great an impression upon him that when he knew the present paper was to be read he had written to his friend, who had replied stating, "The maintenance of the fire-boxes of our locomotives, so difficult before, has become nil; and we do not touch the boilers until the legal time for inspection obliges us to take the tubes out." That was in Germany, where the law was extremely exacting and difficult to be complied with. The writer went on to say, "Our water supply contains 23-10,000ths of carbonate of lime, and after the softening operation there remain only from 3-10,000ths to 4-10,000ths. The cost of the softening varies with the nature of the water: if it contains sulphates, the cost is naturally somewhat higher; but in any case it is extremely low." [See page 453.]

The Presment was reminded by Mr. Maw's observations on the question whether it was better to clean the boiler or to soften the water, that the late Mr. Ramsbottom, when on the London and 
North Western Railway, was always of opinion that it was better to let a boiler get dirty and to take the tubes out and clean it when necessary; and on most railways in this country he believed this opinion had been acted upon for many years past. For the last six years the softening process now described had been in operation on the Midland Railway, and its effect had been very good indeed. In districts where there was good water which, did not require softening, a duty of something like from 400,000 to 500,000 miles was got out of the locomotive fire-boxes; but where the water was bad, they frequently did not run 250,000 miles, and sometimes not more than 200,000 miles. Where the eopper fire-boxes were thickly incrusted, the thinning and wearing of the copper plate was so rapid as to take away quite half its lifetime.

Mr. Aronbetr said that, as regarded the possibility of corrosion in boilers being caused or aggravated by carbonating the water (page 429), the amount of carbonic acid put into the water need be only just sufficient to neutrulise the traces of lime and free carbonate of soda which remained in the water after softening. By the carbonating, these were converted into bi-carbonate of calcium and bi-carbonate of sodium; and no more carbonic acid need be added than was just enough for this purpose. Every natural water contained as much free carbonic acid as water treated by this process contained; and therefore no more corrosive effect could be produced by this softened water than by natural water in the same condition. The presence of the slightest excess of carbonic acid was detected at once by the delicate phenol-phthalein test (page 413); and the apparatus used for carbonating had been proved over and over again to be only just sufficient to answer the purpose. It was an undoubted fact however that some soft natural waters were found to have a seriously corrosive effect on boilers. In a paper, on boiler incrustation and corrosion, read at the Glasgow meeting of the British:Association in 1876 by Mr. F. J. Rowan, reference was made (page 1232 ) to the action of Loch Katrine water, which was of great purity. The former water-supply of Glasgow having been calcareous, boilers using it became coated with scale, and did not afterwards suffer when 
(Mr. Archbutt.)

fed with Loch Katrine water; but new boilers, working with Loch Katrine water from the first, were found to become rapidly corroded. No other cause for this could be discovered save the dissolved gases, of which the water contained from 7 to 8 cubic inches to the gallon, about 3 cubic inches being oxygen. The remedy recommended and found to be effectual was the formation and maintenance of a protective coating of thin hard scale artificially produced. Another proposed remedy, mentioned by Mr. Thornycroft (page 429), was to expel the gases by boiling the water. In the rare instances where chemically softened water might be found to have a similarly corrosive effect, the softening could be limited to a sufficient extent to ensure the formation of a thin protective scale on the boilers, and if necessary carbonating could be dispensed with. In the experiment referred to by Mr. Perks (page 436), which had been made at his own suggestion in 1891, the fuel gas was blown into the water in the storage tank; that was in the early stages of the experiments, and was a method he should not now recommend; he thought it quite possible that the water might at times have been considerably over-carbonated. But he did not feel convinced that the corrosion observed by Mr. Perks was due to carbonic acid, and that it was not the re-commencement of old corrosion, due to the pittings already in the boiler not having been properly cleaned out. The compound which was found in the pittings was magnetic oxide of iron, which was known to be electro-negative in relation to metallic iron, the latter being electro-positive. So long therefore as any oxide of iron remained in the pittings, corrosion would go on; and he thought it probable that water containing free carbonic acid would be more likely to cause it. The proper remedy would be to scrape the pittings down to the hare metal, and paint them with mineral oil or a thin coating of Portland cement.

With regard to the loss of fuel due to incrustation, it would be seen that he had confined himself to quoting authorities in the paper, and had not committed himself to any statement of his own; he was glad the paper had called forth a discussion upon this point, because he thought experiments on the subject were greatly wanted. Having shown that one writer made statements which did 
not agree with those of another, he bad left those statements altogether out of account in estimating the advantages of softening water. Apart from the saving of fuel, there were other advantages in the increased life of the boilers, and in the saving in the cost of cleaning, and so on. What the loss of fuel might be that arose from incrustation, he had no experience which would enable him to express an opinion; and he wished to emphasize the statement in page 425 that the amount of waste which might be caused by incrustation must in any case depend upon the kind of boiler and upon the nature as well as the thickness of the incrustation. A great many experiments therefore would have to be made, before information could be obtained which would apply to all possible cases.

An interesting account had been given by Mr. Ellington (page 433) of the way in which he had succeeded in removing iron from water by the Porter-Clark process. In all the filtering processes however, as Mr. Ellington had found, a great deal of money was spent in the renewal of the filter-cloths; whereas in the process described in the paper it had been shown how filtering could be done away with. If with filtering the cost was $1 \frac{1}{4} d$. per thousand gallons, of which one-third was for filter-eloths, he did not doubt that by the process now described the same water could be softened and purified at two-thirds of that cost.

With regard to alumino-ferric causing corrosion (page 435), he asked whether it was used alone, or whether lime and alkali were used with it.

Mr. Ellington replied that the alumino-ferric only was used.

Mr. Archbot said in that case the corrosion could be understood, because alumino-ferric was a strongly corrosive substance. The quantity which he occasionally found useful for assisting precipitation in softening water did not exceed $1 \frac{1}{2}$ ounce per thousand gallons; and enough lime and carbonate of soda were added to decompose the salt and precipitate the alumina, leaving in the water a small quantity of neutral sulphate of soda: so that no corrosion could possibly take place. 
(Mr. Archbutt.)

From Mr. Herschmann's account of the softening of water in Austria (page 436) he did not gather that there was any difference in the plan there adopted from that in use in England for many years: except that, while lime and caustic soda were used there in just the same way as in England, the softening might be done more cheaply and conveniently by using lime and carbonate of soda, if the apparatus employed were adapted for the purpose.

When the feed-water had been heated by exhaust steam, Professor Lupton bad asked whether there was not a loss of heat by cooling in the subsequent softening (page 436). As an instance of the small amount of loss so arising, he might refer to an apparatus exected at the North British Distillery, where the temperature of the heated water before softening was $100^{\circ} \mathrm{F}$., and after softening $90^{\circ}$, showing a loss of only $10^{\circ}$.

With reference to the precipitation of sulphate of lime by raising the temperature of the water (page 437), he had not felt able to commit himself to any definite statement as to whether sulphate of lime could be completely removed from water by mere heating or not; and had therefore simply quoted the most recent and reliable experiments he was acquainted with, namely those of Professors Tilden and Shenstone (page 407), which showed that on heating water up to $473^{\circ} \mathrm{F}$., and keeping it at that temperature for four or five hours, there would still be nearly 13 grains of sulphate of lime dissolved in a gallon of pure water. It was believed by Mr. Halpin that sulphate of lime was all precipitated by heat; but he should be interested to see the actual figures, showing the result of analytical tests, whereby that belief could be substantiated. Supposing it true that the sulphate of lime was wholly precipitated by heat-and he was not prepared to deny the possibility, though he should like to see it proved-he should be glad to know the cost, as compared with the cost of removing the sulphate of lime by decomposing it by the addition of carbonate of soda (page 409).

Mr. Harpis explained that in the plan of heating water for thermal storage the precipitation of the sulphate of lime was necessarily cffected free of cost, because the essential feature of the 
plan was to heat the water much above the temperature of $302^{\circ} \mathrm{F}$., at which it was stated (page 407) on the authority apparently of Sullivan that sulphate of lime was quite insoluble in water.

Mr. ARchвutr was not convinced that the sulphate of lime could be thus removed; but looking at the question from a practical point of view, under conditions where thermal storage had not yet been adopted, pupposing it were wanted to soften water containing sulphate of lime, and granting this could be done either by raising the temperature or by chemical means, which was the cheaper process?

With regard to the removal of grease by precipitation (page 439), he could not give much information, but would refer to Stingl's paper upon the effects of condensed water containing grease on boilers fed with it.* Only one instance had yet occurred in his own experience in which he had been asked whether softening the water by precipitation would remove traces of grease from the exhaust steam; he had been obliged to reply that he did not know, and that he could not give any opinion. The apparatus was nevertheless put up; and as he had never heard any complaint since, he presumed it had proved satisfactory in removing the grease.

With regard to the corrosion of metallic vessels by cold distilled water, noticed by Mr. Hughes (page 440), he would point out that

* Dinglers Polytechnisches Journal, vol. 215, pages 115-121; and British Association Report, Glasgow 1876, page 231. The condensed steam from two engines was used to feed a stationary boiler constructed of steel. The mixture of condensed and hard water used for feeding the boiler contained per gallon 14 grains of calcium and magnesium carbonates, and 2 grains of calcium sulphate; it had an opalescent appearance due to the presence of grease. After only three weeks' work, water began to leak into the flue-tubes; and shortly afterwards the boiler had to be stopped for examination and repairs. When this had been done, a deposit about 3-8ths inch thick was found on the upper part of the flue-tubes, containing besides chalk and gypsum 12.8 per cent. of oxide of iron and 5.2 per cent. of fatty acids. The water was subsequently softened by means of lime, which precipitated the calcium carbonate and part of the magnesium carbonate along with the grease; and after filtration the purified water was used in the same boiler. After three months' working no ill effect was noticed, a hormless scale being produced, about the thickness of writing paper, and containing only traces of fatty matter. 
(Nr. Archbutt.)

the effect of carbonic acid in cold water was very different from its effect in a boiler. It was matter of common observation that iron would rust in cold water containing dissolved oxygen and carbonic acid, and that the rusting was aggravated by the carbonic acid and free oxygen. As soon as water was put into a boiler and was boiled, the carbonic acid and oxygen were rapidly expelled; and then of course the conditions were totally different.

As to how much water could be evaporated per square foot of heating surface before clcaning, when the water was softened as compared with when it was not softened (page 445), he could answer Mr. Maw's question only in a general way. In water like the London water, which contained chiefly carbonate of lime and which was softened by adding lime alone, as explained in the paper, the carbonate of lime was removed, and nothing was added in its place; such softened water might be evaporated for long periods between successive cleanings of the boiler. But if the water contained sulphate of lime, something must be introduced to decompose the sulphate of lime, namely carbonate of soda, which became transformed into sulphate of soda; and the latter remaining in solution must not be allowed to concentrate, or there would be priming. With such water therefore the boilors must be cleaned out more often; and in his opinion it was desirable that they should be washed out pretty frequently; but the cost of washing out would be trifling, as no scraping or chipping would have to be done.

The President considered this paper was a highly important one to engineers and manufacturers and all who had to deal with the water used in their boilers. Ho could not imagine a more profitable paper; and he was sure the Members would all wish to join in a hearty vote of thanks to Mr. Archbutt.

Mr. JoHN Perks wrote, in reply to Mr. Stromeyer's enquiry (page 441), that in heating the feed-water (page 437) he had a jet of steam blowing into it as soon as the chemicals came in contact with 
it; this caused the sediment to fall immediately to the bottom of the softening tank, whence it was easily blown away through the sludge cock. Heating the water seemed to destroy the tenacious nature of the sediment, because it always lay in a soft mud after the heating.

As regarded the cause of corrosion in the boilers under his charge (page 448), he had been softening the water for about two years before injecting the fuel gas, and they were therefore almost free from scale. Before commencing to use the fuel gas, he had himself examined them, to make sure of their condition; and the only signs of corrosion were slight pittings in the third and fourth plates over the furnaces; the Bowling hoops showed no signs of corrosion whatever. After using the fuel gas one month, he had detected pittings about half an inch in diameter on the Bowling hoops in one of the boilers, which was put to work for another month with the fuel gas; and it was then found that the pittings had increased in number, and some of them were quite 1-32nd inch deep. After yet another month's working it was found they were almost 1-16th inch deep. The injection of fuel gas was then abandoned; and after eight years' more working the pittings were no deeper now than they were at that time.

Mr. A. Tannete Walker, Member of Council, wrote that since the meeting he had heard further from his friend (page 446), who confirmed what he had alreary stated, namely that the fire-boxes of the locomotives had required practically no repairs since using the softened water, and that, although they were dealing with four times the tonnage they had formerly dealt with, the number of men employed to keep them in repair had not increased. These locomotives were running day and night, and were very hard worked, more so in fact than the ordinary locomotives of the main-line railways. The repairs to the fire-boxes were nil; they consisted only in replacing the stays when their heads had been worn out by the coal. The boilers were washed out every week, and no scale was found sticking either to the fire-bozes or to the tubes. The writer added: "In our principal works we purify 98 cubic metres $(=21,562$ gallons) per hour for the forge and the railway. The total expense 
(Mr. A. Tannett Walker.)

per day of twenty-four hours is:-labour 8.02 francs; lime, soda, and sulphate of alumina $9 \cdot 50$; cleaning filters, and maintenance $5 \cdot 04$; total 22.56 francs $(=216.57$ pence). The cost of softening and purifying the water is thus a little less than one centime per cubic metre $(=0.42$ penny per thousand gallons). In the steelworks and in the workshops we have also experienced a great economy in the maintenance of the boilers; we wash them out every month, and nothing sticks to the plates. The boilers connected with heating furnaces work three months without cleaning, thereby enabling us to get many more days' work from the rolling mill than formerly, when the boilers never went three weeks without cleaning, which required the re-heating furnaces to be stopped for three days."

Mr. ARonButr wrote that the effect of heating the softened and clarified water (page 452) was known to Mr. Deeley and himself before they tried carbonating; but the injection of a little carbonic acid was more practicable and less expensive. If it were wished to heat the water instead of carbonating it, it should be softened while hot instead of cold, and not be heated after softening; but in treating large quantities of water, heating would not be practicable, nor would it be permissible where the water was required for drinking and some other purposes. The further explanation given by Mr. Perks (page 453) he thought did not tend to make less obscure the cause of the corrosion described by him. Water softened by the ArchbuttDeeley process and afterwards carbonated was being used at the present time for raising steam in thirty different works, with perfectly satisfactory results so far as he was aware. 
Fig. I. Midland Railway, Derly. Output 30,000 gallons per hour.

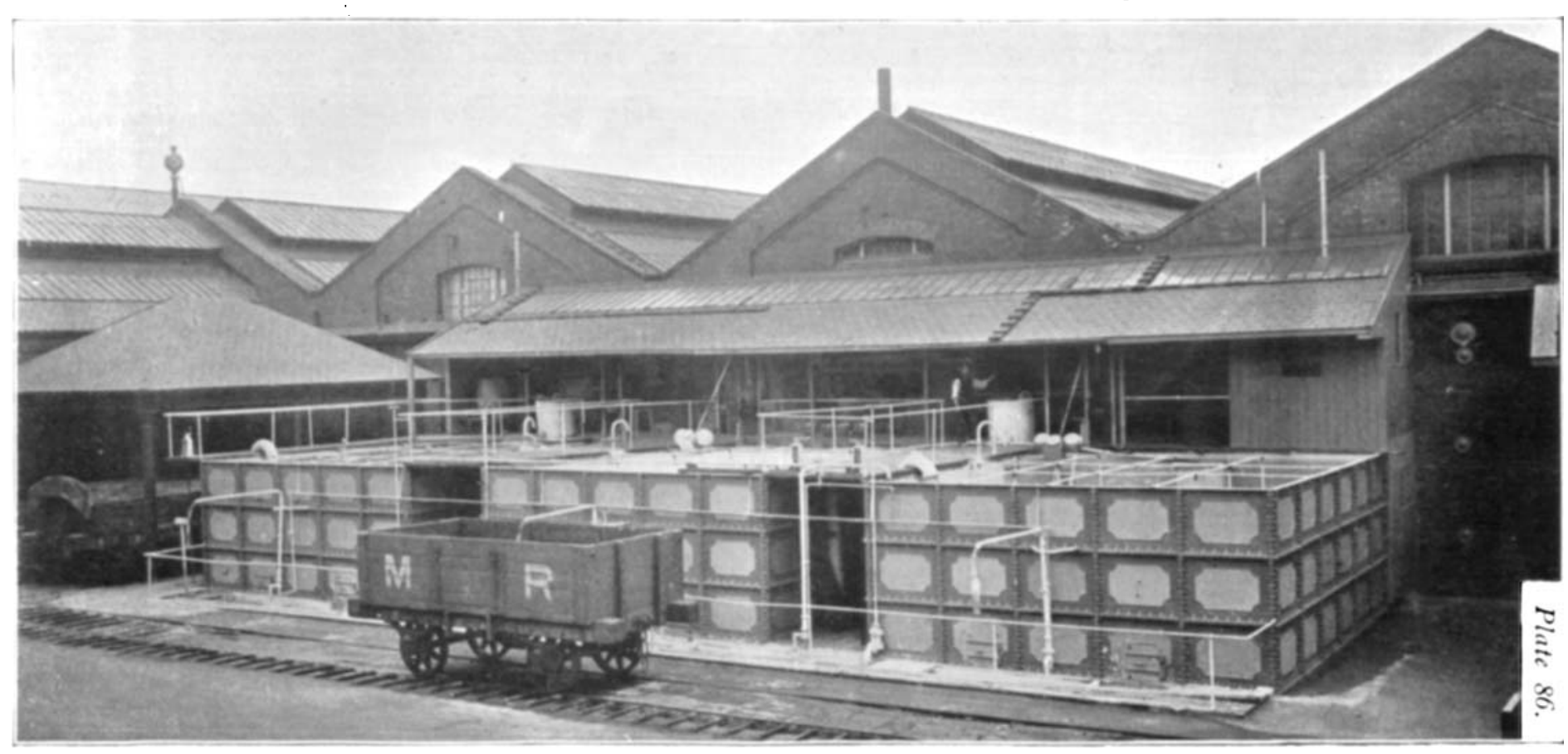


WATER SOFTENING.

Plate 87.

General Arrangement of Apparatus for softening 8,000 gallons per hour.

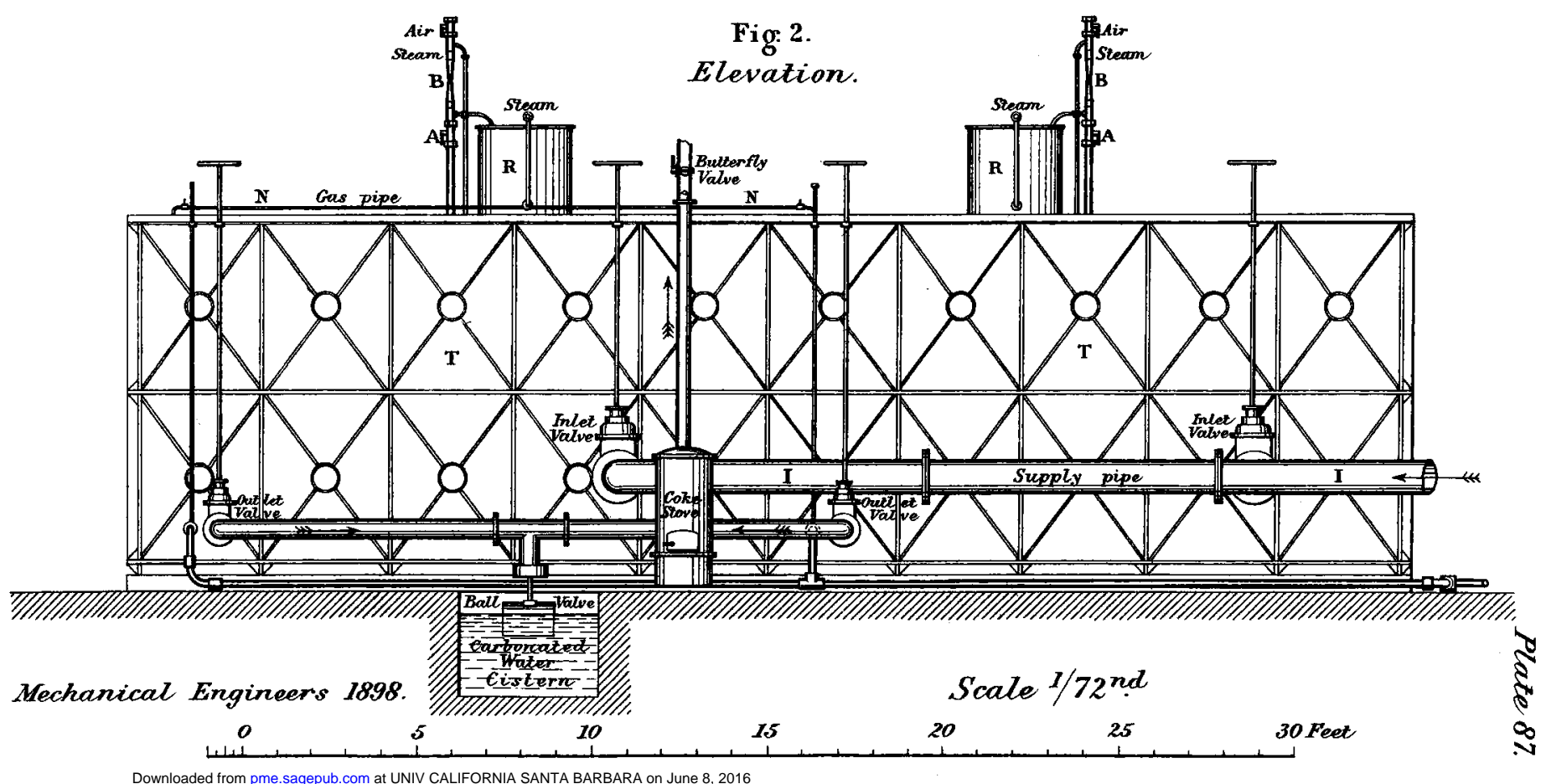


WATER SOFTENING.

Plate 88.

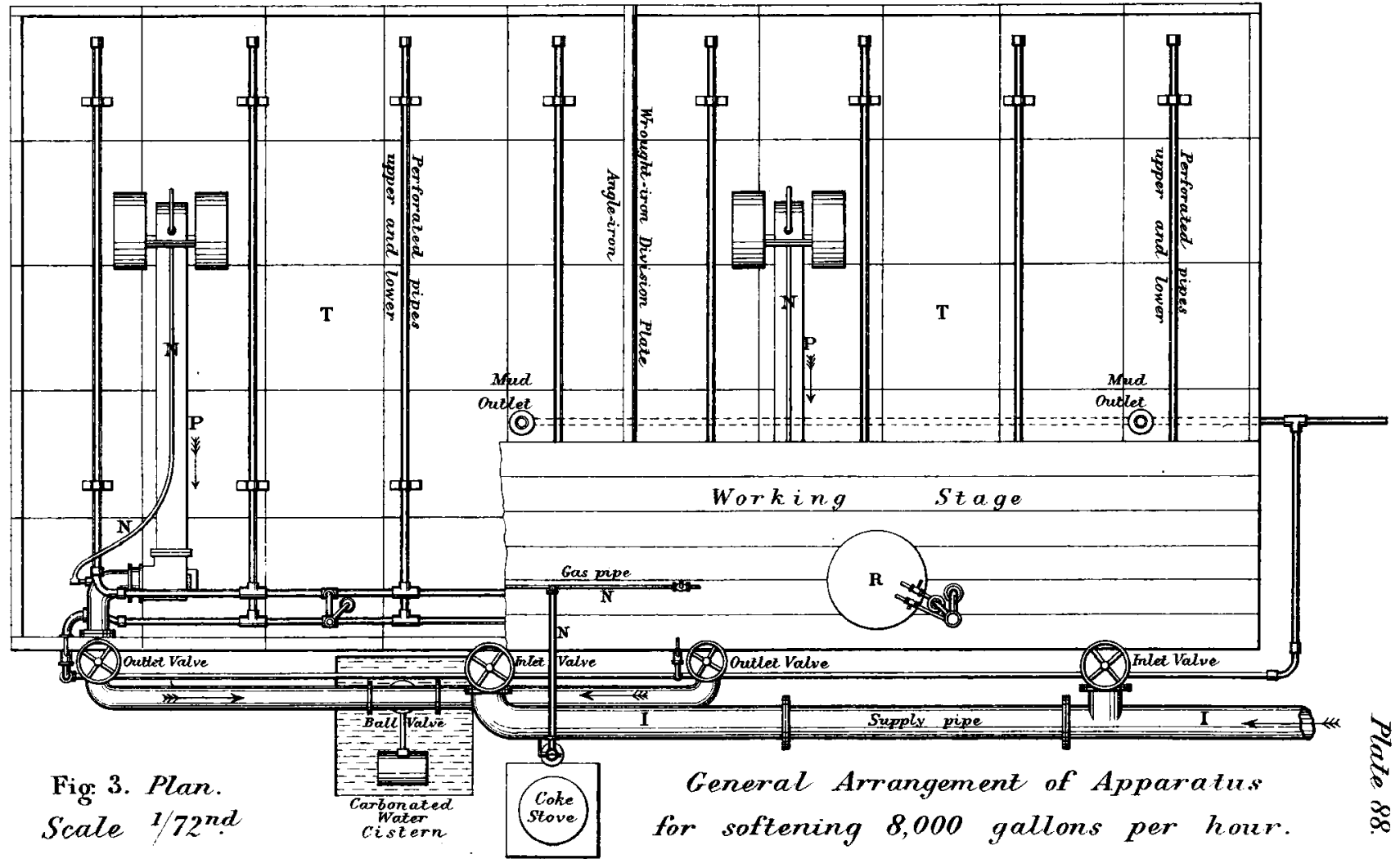


WATER SOFTENING.

General Arrangement of Apparazus

for softening 8,000 gallons per hour.

Fig: 4 .

Transverse Section.

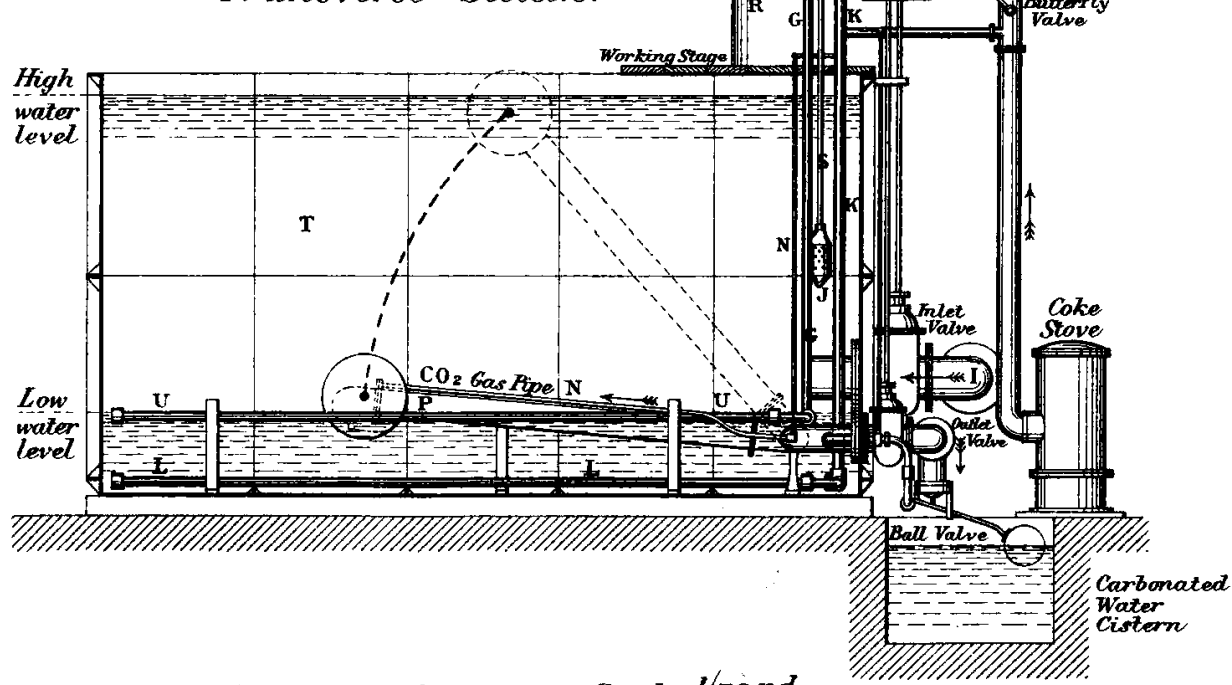

Mechanical Engineers 1898.

Scale $1 / 72^{\text {nd }}$

Downloaded from pme.sagepub.com at UNIV CALIFORNIA SANTA BARBARA on June 8, 2016
Plate 89.

Coke Stove for Carbonating.

Fig: 5. Vertical Section.

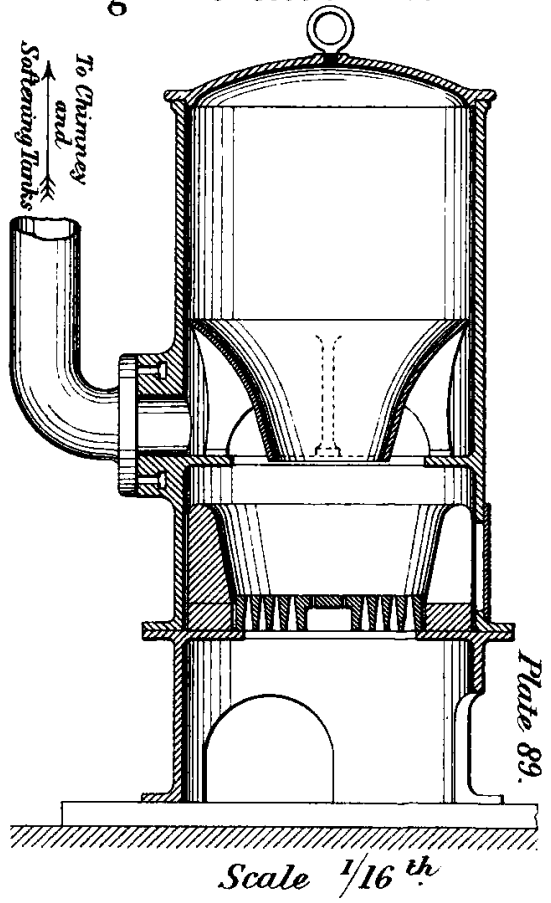


Floating Disrhmge Pipe in softening tank.

Fig: 6. Longitudinal Section.
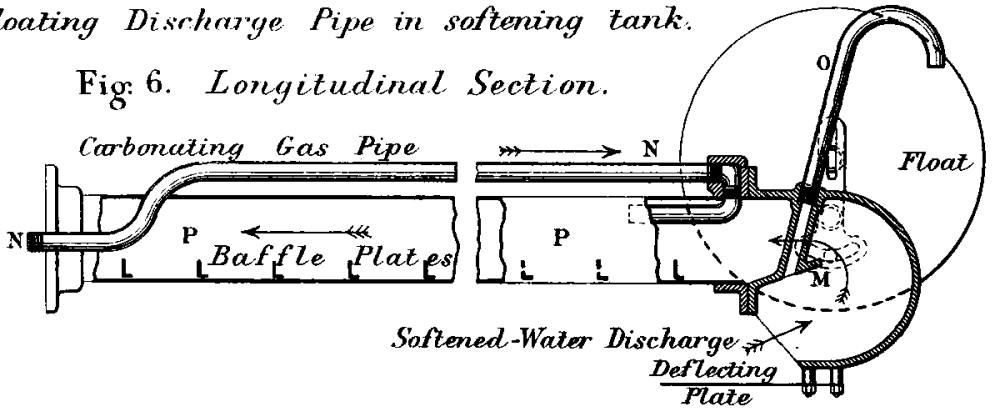

Softened-Water Discharge - Deffecting
Plate

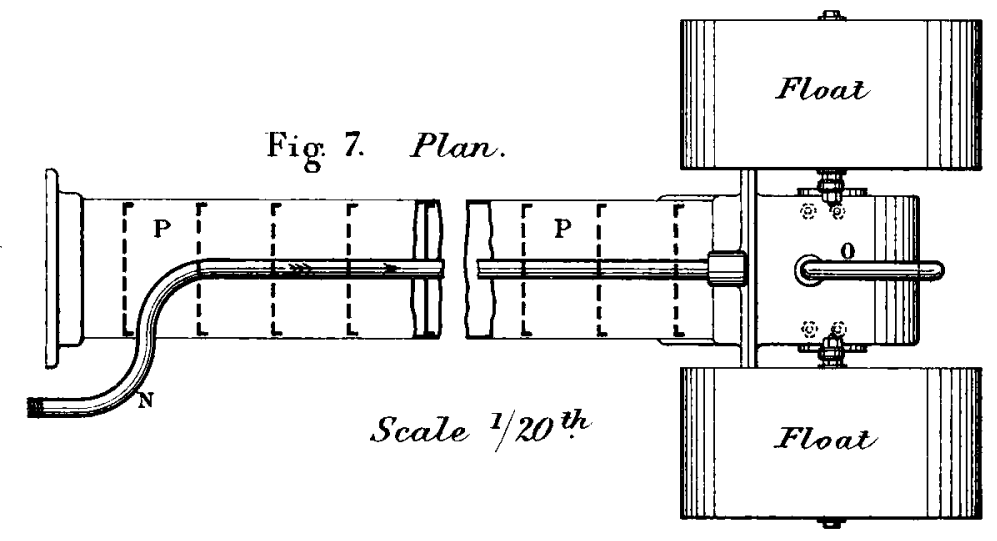

Reagent Tank, (요 AirTap Blower;

and connections.

Mechanical

Engineers 1898.

Fig: 8.

Elevation.

Scale $1 / 16^{\text {th }}$ 
WATER SOFTENING.

Plate 91.

Reagent Tank, Blower, and connections.

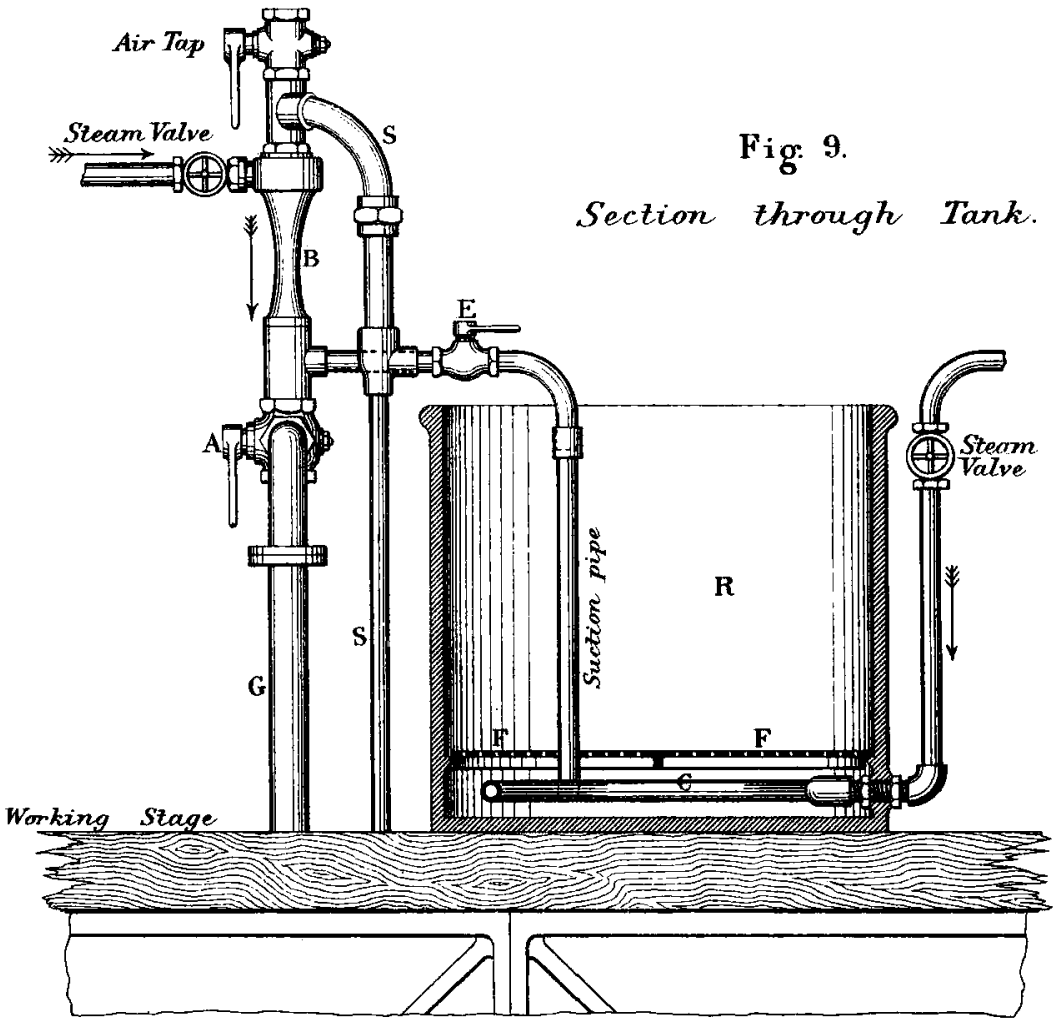

Fig 10. Plan.

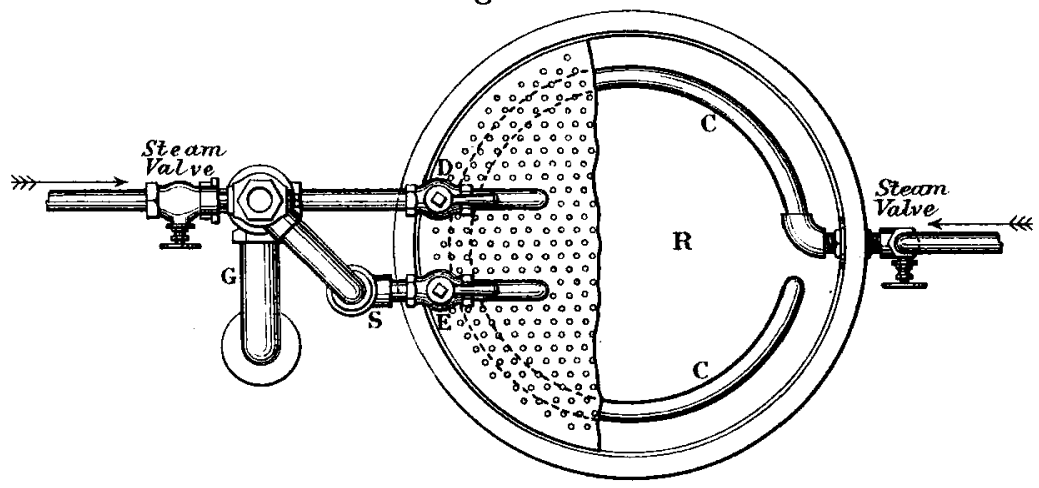

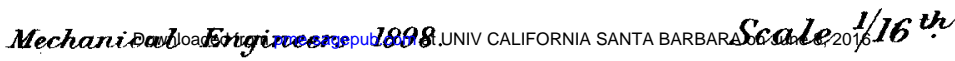


Fig: 11.

Table 1.

Solobility of Sulphate of Lime in pure water.

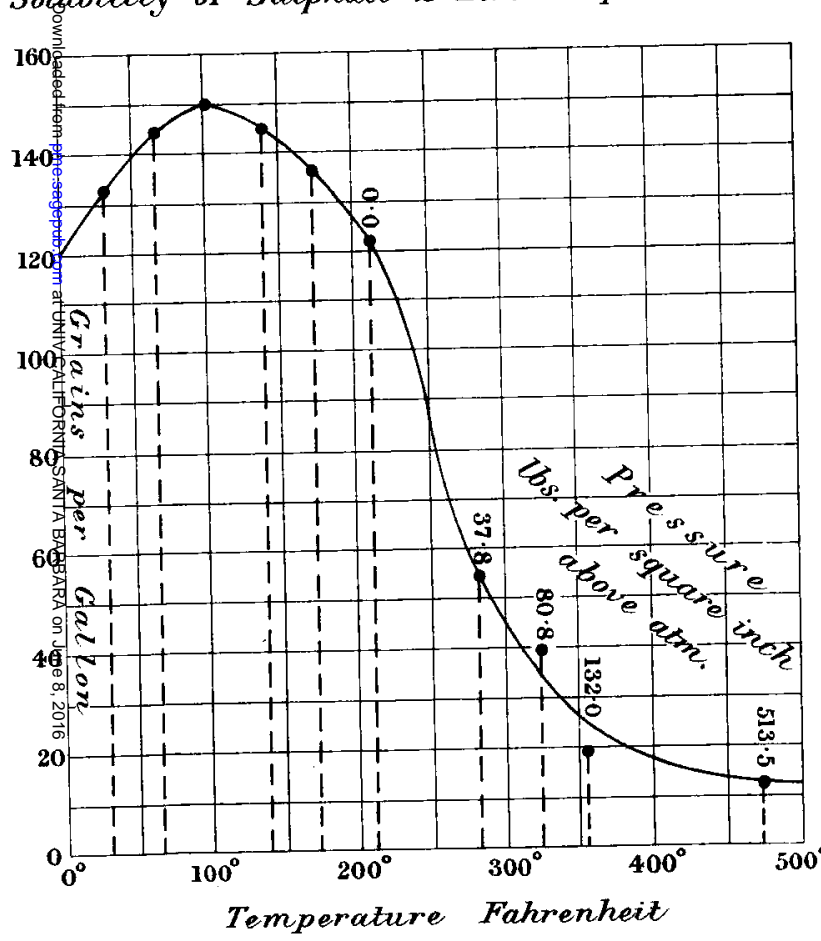

WATER SOFTENING.

Analyses of River Derwent Water.

\section{UNSOFTENED}

Fig. 12.

Carbonate of Lime

Carbonate of Magnesia

Sulphate of Lime

Sulphate of Magnesia Sulphate of Soda 10.41 Comman Salt

Vitrate of Soda $\mathrm{NatO} 0.28$ Silica 0.50 .34

Water at $266^{\circ} \mathrm{F}$.

Organic Matter, \&c. 1.711 年

Tozal $\overline{2200}$

Degrees of Hardness 154
Fig: 13.

Plate 92.

Cost of Softening

1,000 gallons of water of 20 degrees hardness.

Three different waters.

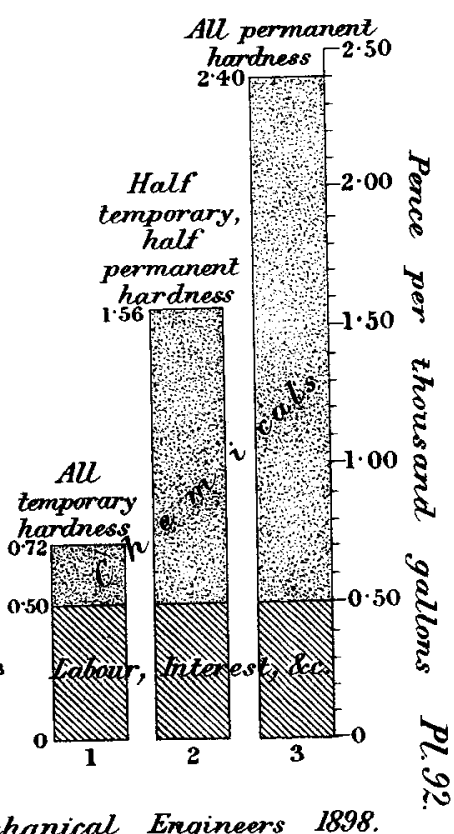


Swadlincote and Ashby Water Works.

Fig. I4. General View. Output 45,000 gallons per hour.

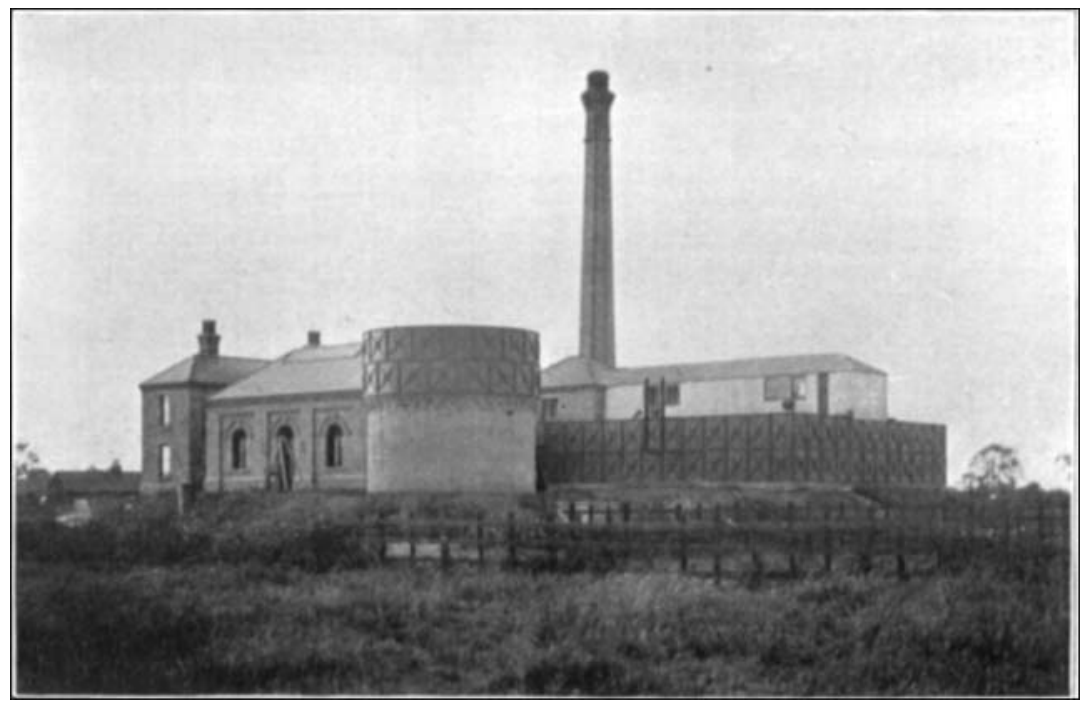

Fig. I5. Chemical Treating House and Tanks.

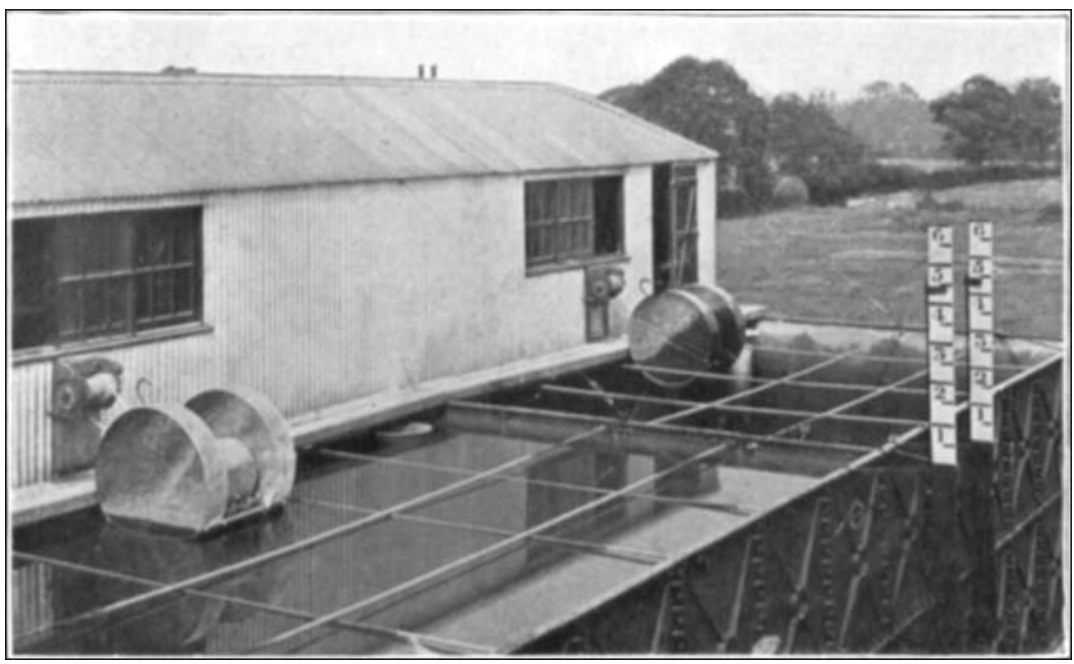

Downloaded from pme.sagepub.com at UNIV CALIFORNIA SANTA BARBARA on June 8, 2016 Mechanical Engineers 1898. 
Sicadlincote and Ashby Water Works.

Figr. 16. Chemical Treating House.

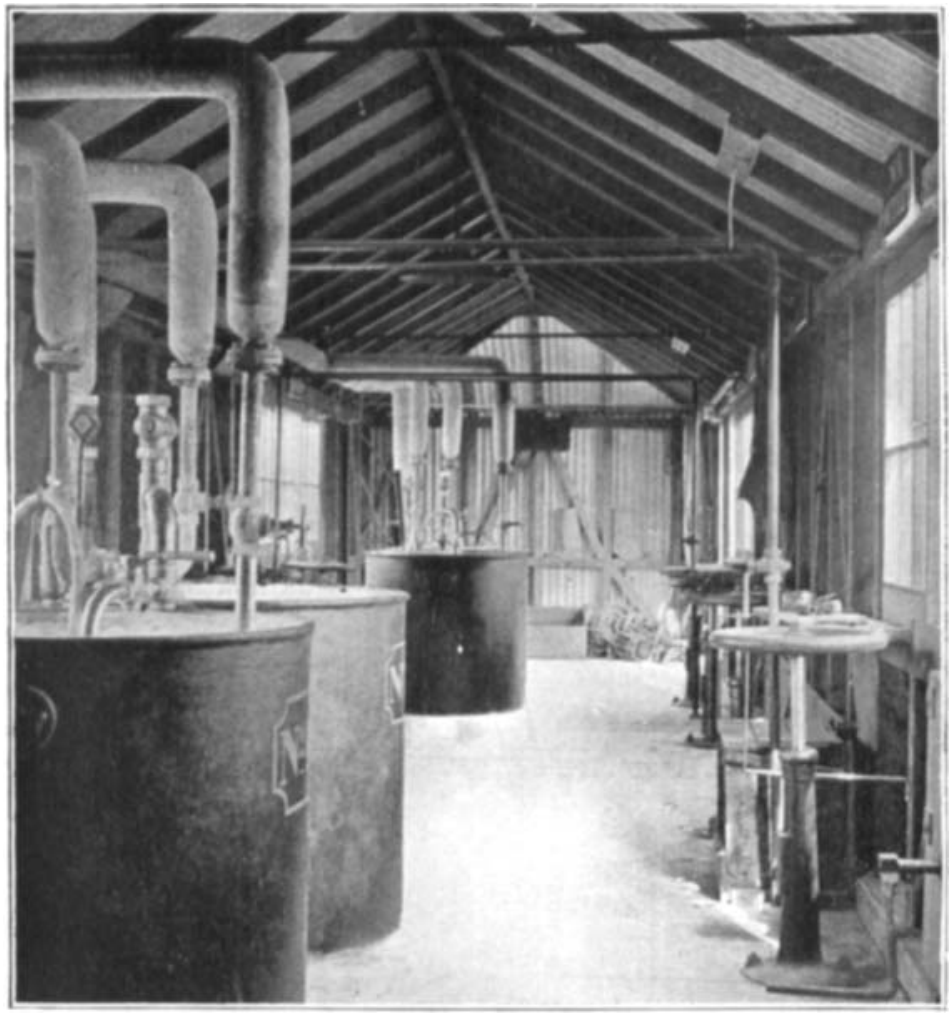

Fig. I7. Gelatine Cultivations

in 0.018 cubic inch of River Derqent water. BEFORE purification. AFTER purification.

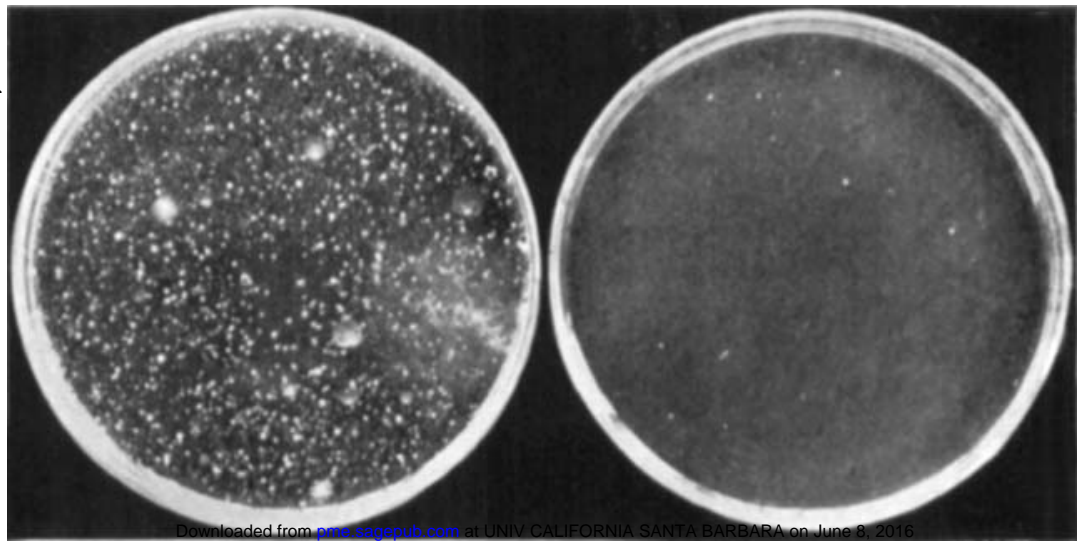


Fig. I8. Standish Bleach and Dye Works, Wigan.

Clarification of Waste Water.

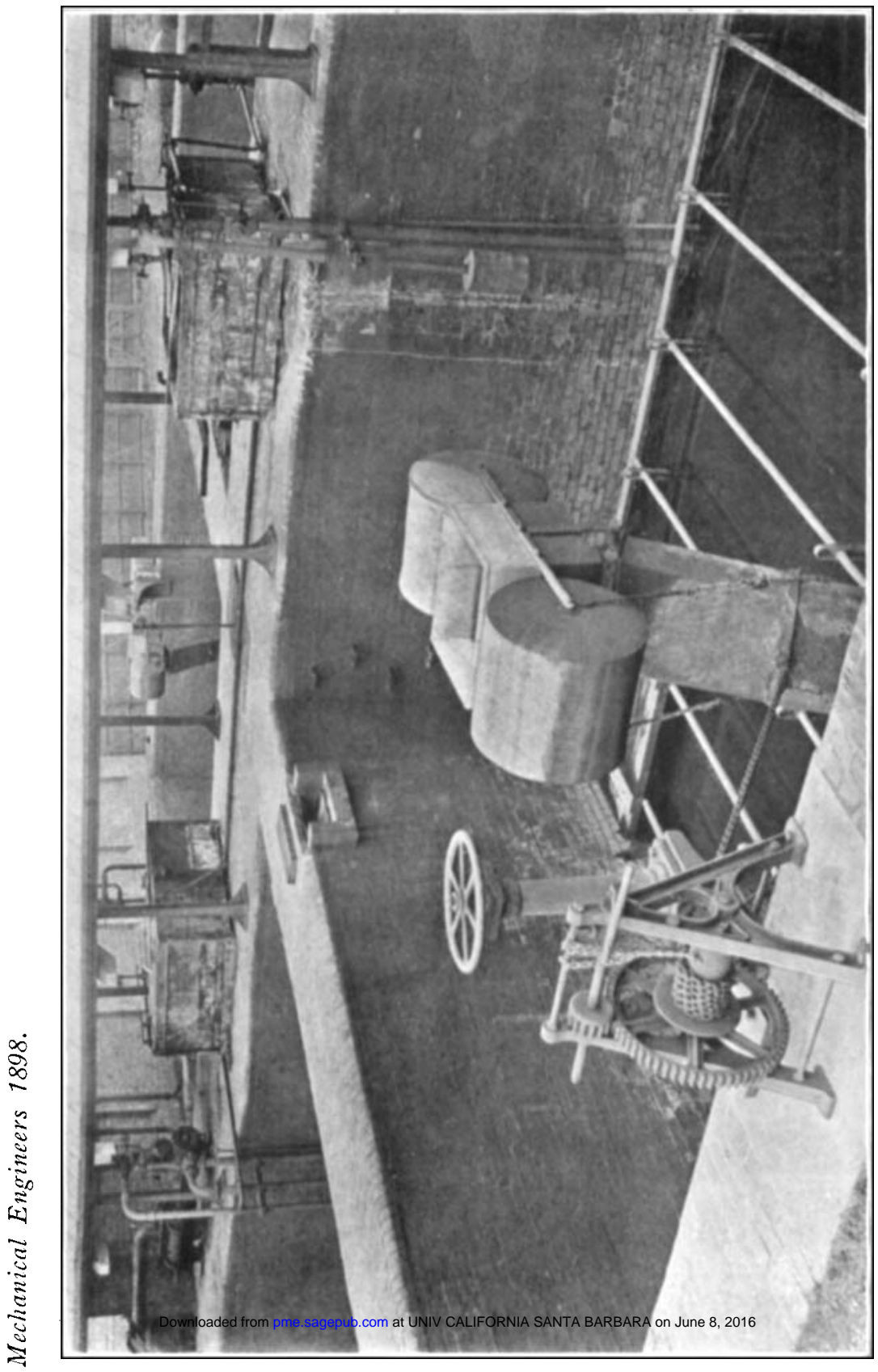

